\title{
Chemical fingerprint of iron oxides related to iron enrichment of banded iron formation from the Cauê Formation - Esperança Deposit, Quadrilátero Ferrífero, Brazil: a laser ablation ICP-MS study \\ Assinatura química de óxidos de ferro associados ao enriquecimento em ferro na Formação Ferrífera Bandada Cauê - Depósito de Esperança, Quadrilátero Ferrífero, Brasil: um estudo por ablação a laser ICP-MS
}

\author{
Lucilia Aparecida Ramos de Oliveira ${ }^{1 *}$, Carlos Alberto Rosière ${ }^{2}$, \\ Francisco Javier Rios ${ }^{3}$, Sandra Andrade ${ }^{4}$, Renato de Moraes ${ }^{4}$
}

\begin{abstract}
Chemical signatures of iron oxides from dolomitic itabirite and high-grade iron ore from the Esperança deposit, located in the Quadrilátero Ferrífero, indicate that polycyclic processes involving changing of chemical and redox conditions are responsible for the iron enrichment on Cauê Formation from Minas Supergroup. Variations of $\mathrm{Mn}, \mathrm{Mg}$ and $\mathrm{Sr}$ content in different generations of iron oxides from dolomitic itabirite, high-grade iron ore and syn-mineralization quartz-carbonate-hematite veins denote the close relationship between high-grade iron ore formation and carbonate alteration. This indicates that dolomitic itabirite is the main precursor of the iron ore in that deposit. Long-lasting percolation of hydrothermal fluids and shifts in the redox conditions have contributed to changes in the $\mathrm{Y} / \mathrm{Ho}$ ratio, light/heavy rare earth elements ratio and $\mathrm{Ce}$ anomaly with successive iron oxide generations (martite-granular hematite), as well as lower abundance of trace elements including rare earth elements in the younger specularite generations.
\end{abstract}

KEYWORDS: high-grade iron ore; geochemistry; iron oxide; LA-ICP-MS analysis.
RESUMO: As assinaturas químicas dos óxidos de ferro presentes no itabirito dolomítico e no minério de ferro de alto teor do Depósito de Esperança, localizado no Quadrilátero Ferrifero, indicam que processos policíclicos envolvendo mudanças nas condiçôes quimicas e de redox são responsáveis pelo enriquecimento em ferro na Formação Cauê do Supergrupo Minas. A variação nos conteúdos relativos de $\mathrm{Mn}, \mathrm{Mg}$ e Sr nas diferentes geraçóes de óxidos de ferro encontradas no itabirito dolomitico, no minério de ferro de alto teor e nos veios de quartzo-carbonato-hematita associados à mineralização denotam uma estreita relação entre a formação do corpo de minério de ferro de alto teor e a alteração dos carbonatos. Isso indica que o itabirito dolomítico é o principal precursor do corpo de minério naquele depósito. Percolação de longa duração de fuidos hidrotermais e mudança nas condiçōes de redox contribuiram para a alteração das razóes $Y / H o$, elementos terras raras leves/pesados e da anomalia de Ce com sucessivas geraçóes de óxido de ferro (martita-hematita granular), bem como depleção dos conteúdos de elementos traço, incluindo os elementos terras raras das geraçôes mais recentes de especularita.

PALAVRAS-CHAVE: minério de ferro de alto teor; geoquimica; óxido de ferro; análise por LA-ICP-MS.

\footnotetext{
1Programa de Pós-Graduação em Geologia, Instituto de Geociências, Universidade Federal de Minas Gerais - UFMG, Belo Horizonte (MG), Brazil. E-mail: luciliar@gmail.com 2Instituto de Geociências, Universidade Federal de Minas Gerais - UFMG, Belo Horizonte (MG), Brazil. E-mail: crosiere@gmail.com ${ }^{3}$ Centro de Desenvolvimento da Tecnologia Nuclear - CDTN/CNEN, Belo Horizonte (MG), Brazil. E-mail: javier@cdtn.br 4Instituto de Geociências, Universidade de São Paulo - USP, São Paulo (SP), Brazil. E-mail: sandrade@usp.br; moraes@igc.usp.br *Corresponding author
}

Manuscript ID: 30190. Received: 10/27/2014. Approved: 04/24/2015 


\section{INTRODUCTION}

The genesis of high-grade iron ore bodies has been extensively discussed worldwide. Different processes such as hydrothermal syn-metamorphic (Guild 1953, 1957; Dorr 1965, 1969), residual supergene (Dorr 1964; Eichler 1968; Melfi et al. 1976), or paleo-supergene enrichment (Morris 1980, 1987; Harmsworth et al. 1990), and the juxtaposition of hypogene and supergene fluids (Hagemann et al. 1999, 2005; Powell et al. 1999; Taylor et al. 2001; Rosière \& Rios 2004) are considered to be responsible for the iron enrichment.

In most of the large iron deposits, Fe enrichment appears to be a multistage process involving hydrothermal leaching of gangue minerals (Taylor et al. 2001; Hagemann et al. 2005) and Fe remobilization. Rosière \& Rios (2004) have documented in the Conceição Mine (Quadrilátero Ferrífero) an association of several iron oxide generations with different mineralization stages.

In situ trace element geochemistry studies by Laser Ablation - Inductive Coupled Plasma - Mass Spectrometer (LA-ICP-MS) are expected to shed some light on the understanding of the mineralization processes that have led to the iron ore concentration in the Esperança deposit, located in the Quadrilátero Ferrífero. They help to trace the geochemical signature of the different iron oxide generations, to constrain the physico-chemical conditions of their formation and their compositional evolution with time (Nadoll et al. 2014). In this study, samples of highgrade massive ore and fibrous quartz-carbonate-specularite veins, both hosted in dolomitic itabirite, from the Esperança deposit, are examined using LA-ICP-MS. Fibrous quartz-carbonate-specularite assemblages grow upon opening of the veins and consequently offer constrains on fluid conditions at the time of fracturing during syn-kinematic mineralization (Rosière et al. 2001). Iron oxide microchemistry reflects the variation in the fluid composition and the prevailing physico-chemical conditions during the process thus enabling to draw important conclusions about the transformations associated with the different stages of mineralization.

\section{Geological setting of the Quadrilátero Ferrífero}

The Quadrilátero Ferrifero district is located in the central part of Minas Gerais, southeastern Brazil (Fig. 1), where itabirites, a metamorphic variety of Banded Iron Formation (BIF) (Rosière et al. 2008; Hagemann et al. 2008), of the Cauê BIF from the Minas Supergroup, host high-grade iron ore bodies ( $\mathrm{Fe}>64 \mathrm{wt} \%)$. The ore is comprised mainly of magnetite and martite (hematite pseudomorph after magnetite) aggregates and younger hematite crystals that display a wide variety of microstructures and textures (Rosière et al. 2001, 2013a, 2013b).

The platformal units of the Minas Supergroup were deposited at the SE border of the Archean São Francisco paleocontinent (Ávila et al. 2010) with the onset of deposition at about -2600 to $2520 \mathrm{Ma}$ as indicated by U-Pb ages for detrital zircons from the basal Moeda quartzites (Machado et al. 1992, 1996; Renger et al. 1994; Hartmann et al. 2006). The rocks exhibit structures that are the product of two main orogenic events (Machado \& Carneiro 1992; Chemale Jr. et al. 1994; Alkmim \& Marshak 1998; Noce et al. 1998; Rosière et al. 2001): the Transamazonian $(2.1-2.0 \mathrm{Ga})$ and the Pan-African/ Brasiliano (0.8 - 0.6 Ga; Rosière et al. 2001). During the early Transamazonian orogeny (Rosière et al. 2013a), structurally controlled, high-grade martite-hematite iron ore bodies of hypogene origin formed in the Cauê BIF, as discussed by Guild (1953, 1957), Dorr (1965) and Rosière and Rios (2004). Two penecontemporaneous events developed significant folds and related faults with northeast-southwest and northwest-southeast orientations, which constrain the alignment and location of the ore bodies (Rosière et al. 2008).

\section{Dolomitic itabirite and the hypogene enrichment of banded iron formation in the Quadrilátero Ferrífero}

Hypogene enrichment of the itabirite is the main ore-forming process in the Quadrilátero Ferrífero (Rosière \& Rios 2004; Rosière et al. 2008). In this region, hydrothermal fluids interacted with the BIF protolith during the Transamazonian orogeny (Rosière et al. 2013a) resulting initially in the formation of magnetite-rich, high-grade ore bodies. Later hypogene fluids, probably modified by ancient meteoric waters, seeped through the fault zones and were responsible for the oxidation of the magnetite protore. This resulted in martite aggregates and younger precipitated and recrystallized hematite crystals (Rosière \& Rios 2004). In granoblastic domains, hematite grains comprise a fabric of anhedral to subhedral grains with elongated platelets that occur as fillings in veins, voids and vugs in the interstices of martite-hematite aggregates. In schistose domains, associated with highly strained zones, platy crystals exhibit a preferred orientation with the development of a continuous foliation. The mineralogical changes during mineralization are associated with the remobilization of large amounts of dolomite, quartz, lesser iron oxide and the substantial development of veins. Mining developments beneath the water table (Spier et al. 2003) have shown that, although high-grade ore bodies may be 
hosted by quartz-rich itabirite, the dolomitic variety represents its most important protolith. Dolomitic itabirite has been observed in the Águas Claras (Spier et al. 2003), Esperança and other deposits in the Quadrilátero Ferrífero.

Dolomitic itabirite is one of the mineralogical facies distinguished by Dorr $(1964,1965,1969)$ and Dorr and Barbosa (1963). It combines the characteristics of BIFs and marine dolostones with large amounts of iron oxides and texturally it is very similar to quartz itabirites. Spier et al. (2007) interpret these rocks from the Itabira Group as the product of diagenetic processes under unusual conditions at the final stages of Paleoproterozoic iron deposition. Morgan et al. (2013), using mineralogical investigations combined with rare earth elements behavior and trace elements geochemistry, proposed a mixed marine-hydrothermal origin for these rocks. In contrast, Beukes et al. (2003), based on deep drilling and mining data, consider these rocks to be a product of hypogene alteration of quartz itabirite during carbonate metasomatism which has substituted silica by iron-rich dolomite.

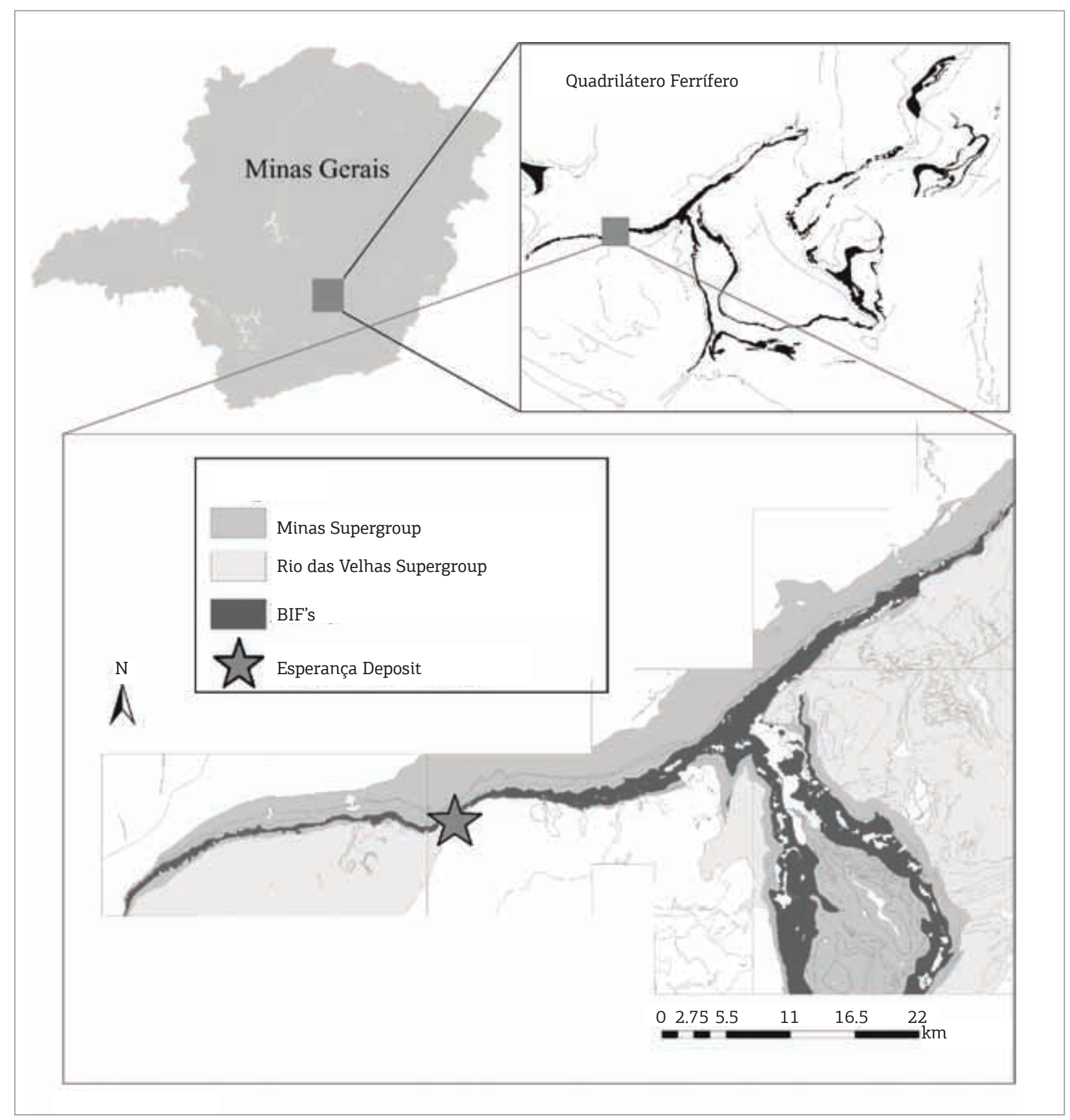

Figure 1. Simplified geological map of the northwestern area of the Quadrilátero Ferrifero highlighting the location of the Esperança deposit. 


\section{Esperança Deposit}

The Esperança Deposit is located in the northwestern part of the Quadrilátero Ferrífero, in the western branch of the Serra do Curral Ridge, near Brumadinho, Minas Gerais (Fig. 1). This deposit is currently being exploited by Ferrous Resources. According to internal reports, the available reserves comprise 339 million tons of high (> 60\% Fe) and low-grade $(30-60 \% \mathrm{Fe})$ weathered friable dolomite-bearing ore with a production capacity of 2 million tons/year.

The regional structure is controlled by NE-SW trending folds and related thrusts, partially overlapped by a second group of NNW-SSE trending folds (Sanglard et al. 2011). According to these authors, the structural arrangement led to the development of open spaces and strain gradients that allowed the circulation of fluids responsible for the hypogene alteration and mineralization of the BIF.

Dolomitic itabirite exhibits a large variety of minerals, including iron oxides, quartz, dolomite/ankerite, minor calcite and silicates such as chlorite, amphiboles (cummingtonite, grunerite), stilpnomelane and talc/minnesotaite. A wedge-shaped, near-vertical, massive high-grade ore body is hosted by dolomitic itabirite. The ore body trends NE-SW and cuts the layers of the Cauê Formation narrowing with depth (Sanglard 2013). The contact between the ore body and dolomitic itabirite is sharp. The high-grade ore body comprises magnetite-martite-maghemite and hematite-specularite that grows either as xenoblastic or idioblastic crystals. The relatively small size of the ore body $(-120 \mathrm{~m}$ thickness) allows the identification of hypogene alteration zones, which include several vein generations comprising carbonate, quartz, iron oxide, minor chlorite, amphiboles, stilpnomelane and rare sulfides.

\section{MATERIALS AND METHODS}

LA-ICP-MS analyses were performed at the Chemistry and ICP Laboratory, part of the NAP GeoAnalítica Geoscience Institute, University of São Paulo (USP), using a quadrupole ICP-MS spectrometer, ELAN 6100DRC, Perkin Elmer/ Sciex ${ }^{\mathrm{TM}}$, and a New Wave Laser Ablation system, model UP-213 A/F with super cell.

Analytical conditions were:

1. laser energy for mineral ablation $3.5 \mathrm{~J} / \mathrm{cm}^{2}$,

2. laser pulse frequency $10 \mathrm{~Hz}$,

3. ablation carrier gas was $\mathrm{He}(0.5 \mathrm{~L} / \mathrm{min})$, and

4. Ar at $0.5 \mathrm{~L} / \mathrm{min}$ for transport to the ICP, RF Power $1,300 \mathrm{~W}$.

The laser diameter ( 40 to $65 \mu \mathrm{m}$ ) and the hole depth (10 to $15 \mu \mathrm{m}$ ) varied depending on the size and shape of the crystal and for some analyses a spot or a raster was used. The dwell times were also variable for each element $(8.3,16.7$, and $25 \mathrm{~ms})$.

The elements analyzed by LA-ICP-MS in all iron oxides were: $\mathrm{Li}^{7}, \mathrm{Na}^{23}, \mathrm{Mg}^{26}, \mathrm{Al}^{27}, \mathrm{Si}^{29}, \mathrm{P}^{31}, \mathrm{Ti}^{49}, \mathrm{~V}^{51}, \mathrm{Cr}^{53},{ }^{57} \mathrm{Fe}$, $\mathrm{Mn}^{55}, \mathrm{Co}^{59}, \mathrm{Ni}^{60}, \mathrm{Cu}^{63}, \mathrm{Zn}^{66}, \mathrm{Ga}^{71}, \mathrm{As}^{75}, \mathrm{Sr}^{88}, \mathrm{Y}^{89}, \mathrm{Zr}^{90}, \mathrm{Nb}^{93}$, $\mathrm{Mo}^{95}, \mathrm{Sb}^{121}, \mathrm{Cs}^{133}, \mathrm{Ba}^{137}, \mathrm{La}^{139}, \mathrm{Ce}^{140}, \mathrm{Pr}^{141}, \mathrm{Nd}^{144}, \mathrm{Sm}^{147}$, $\mathrm{Eu}^{153}, \mathrm{Gd}^{156}, \mathrm{~Tb}^{159}, \mathrm{Dy}^{161}, \mathrm{Ho}^{165}, \mathrm{Er}^{166}, \mathrm{Tm}^{169}, \mathrm{Yb}^{173}, \mathrm{Lu}^{175}$, $\mathrm{Pb}^{208}, \mathrm{Bi}^{209}, \mathrm{Th}^{232}$, and $\mathrm{U}^{238}$.

The reference material (RM) Nist-610 (NIST-USA) was used as external calibration standard. Besides the low iron content in NIST-610 $(458 \mu \mathrm{m} / \mathrm{g})$, it is considered an adequate external standard. Iron $(\mathrm{Fe})$ was applied as an internal calibration standard, to correct drift and fractionation.

The RM BHVO-2G $(\mathrm{FeO}=11.3 \%)$ was provided by United States Geological Survey (USGS), characterized by LA-ICP-MS (Gao et al. 2002), and has the data compiled by GEOREM (2014). BHVO-2G was used as a quality control standard in order to verify the accuracy of the obtained results (Appendices 1 and 2).

All the results were processed by Glitter Software (Access Macquarie LTD), developed by GEMOC National Key Center, Macquarie University, Australia. The mean and median values of the analyzed elements in BHVO-2G are similar to the values obtained by Gao et al. (2002). Coefficients of variation (\%CV; Horwitz 1982) are inside of the interval from 80 to $120 \%$ of the values proposed by Gao et al. (2002) (Appendix 1), that are expected for concentration levels analyzed by LA-ICP-MS. The elements $\mathrm{Sb}(56 \%), \mathrm{Pb}(137 \%)$, and $\mathrm{Si}(123 \%)$ are the only ones out of these $\mathrm{CV}$ and perhaps with a major set of data this deviation could be corrected.

The relative standard deviation (rsd) obtained for the samples and BHVO-2G was above the quantitation limit (3.33 of the detection limit). Usually, the precision represented by rsd is $10-15 \%$. However, whether obtained values for the elements approach the detection limit, the rsd values are increased as observed in $\mathrm{Bi}, \mathrm{As}$, and $\mathrm{Sb}$ from BHVO-2G and other elements from analyzed samples (Appendices 1 to 3).

\section{Analyzed samples}

For the purpose of evaluating chemical changes in iron oxides during mineralization, hematite grains from a single sample of dolomitic itabirite (DI) and two samples of hard high-grade iron ore (HIO1 and HIO2) from the Esperança Deposit (Figs. 2 to 4) were analyzed. Sample $\mathrm{DI}$ and HIO1 were collected from the diamond drill core FD024 (UTM: E58103.44/N7776096.03) at depths of $249 \mathrm{~m}$ for DI and of $70 \mathrm{~m}$ for HIO1. Sample HIO2 
was collected from a digging face in the open pit (UTM: E580930.272/N7776104.693).

Sample DI is a fine-grained banded rock, with gray iron oxide bands alternating with red dolomite bands. $\mathrm{Mm}$ - to $\mathrm{cm}$-wide crack-seal veins composed mainly of quartz, carbonate and specular hematite cut the sampled rock (Figs. 2A and $2 \mathrm{~B}$ ). The prevailing iron oxide of the banded iron formation is anhedral granular hematite $(\mathrm{gHmA})$ with pinkish (dark gray in Fig. 2D) relics of kenomagnetite ( $\mathrm{kmg}$ ) although several subhedral to euhedral martite crystals are intergrown with the hematite aggregates (Figs. 2C and 2D). The reddish dolomite layers comprise mainly subhedral to anhedral grains with straight or lobed boundaries with subordinate quartz and calcite. Accessory minerals include talc, amphibole and chlorite.

Sample HIO1 is a fine to medium grained $(<50 \mu \mathrm{m})$, massive high-grade iron ore (Fig. 3A) with a brecciated fabric. The rock is comprised by aggregates of granoblastic hematite/martite (gHmB: - 90 vol\%) with kenomagnetite relics (Fig. 3B) similar to those observed in the DI. Large platy hematite (spH1A: $100-500 \mu \mathrm{m})$ grows in apparent vugs surrounded by hematite-martite aggregates (Fig. 3C), whereas elongated coarse platy crystals (specularite - spH1B: $>500 \mu \mathrm{m}$ ) build irregular-shaped sheaves filling open spaces or fractures (Fig. 3D). Sample HIO2 is similar to HIO1 (Figs. 4A and 4B), although lacking microplaty hematite or specularite in the interstices. A cm-long extensional vein filled with syntaxially grown fibrous specularite and quartz cuts across the sample.

Two distinct fibrous veins have been selected for analysis: 1. Carbonate-quartz-specularite vein in DI (Fig. 5A). Crystals are medium- to coarse-grained $(>200 \mu \mathrm{m})$, which grew asymmetrically as syntaxial, elongated, straight to slightly curved fibers of calcite and dolomite, perpendicular to the sharp contact between the vein and the wallrock. Thin specularite plates ( $\mathrm{spH} 2 \mathrm{~A})$ grow from the iron oxide bands giving a "layered" structure to the vein (Figs. 5B and 5C). Quartz occurs as fibers in the middle of the vein together with specularite. On the other vein margin, carbonate grains are short and grow oblique to the wallrock towards the center. Chlorite crystals are also observed.
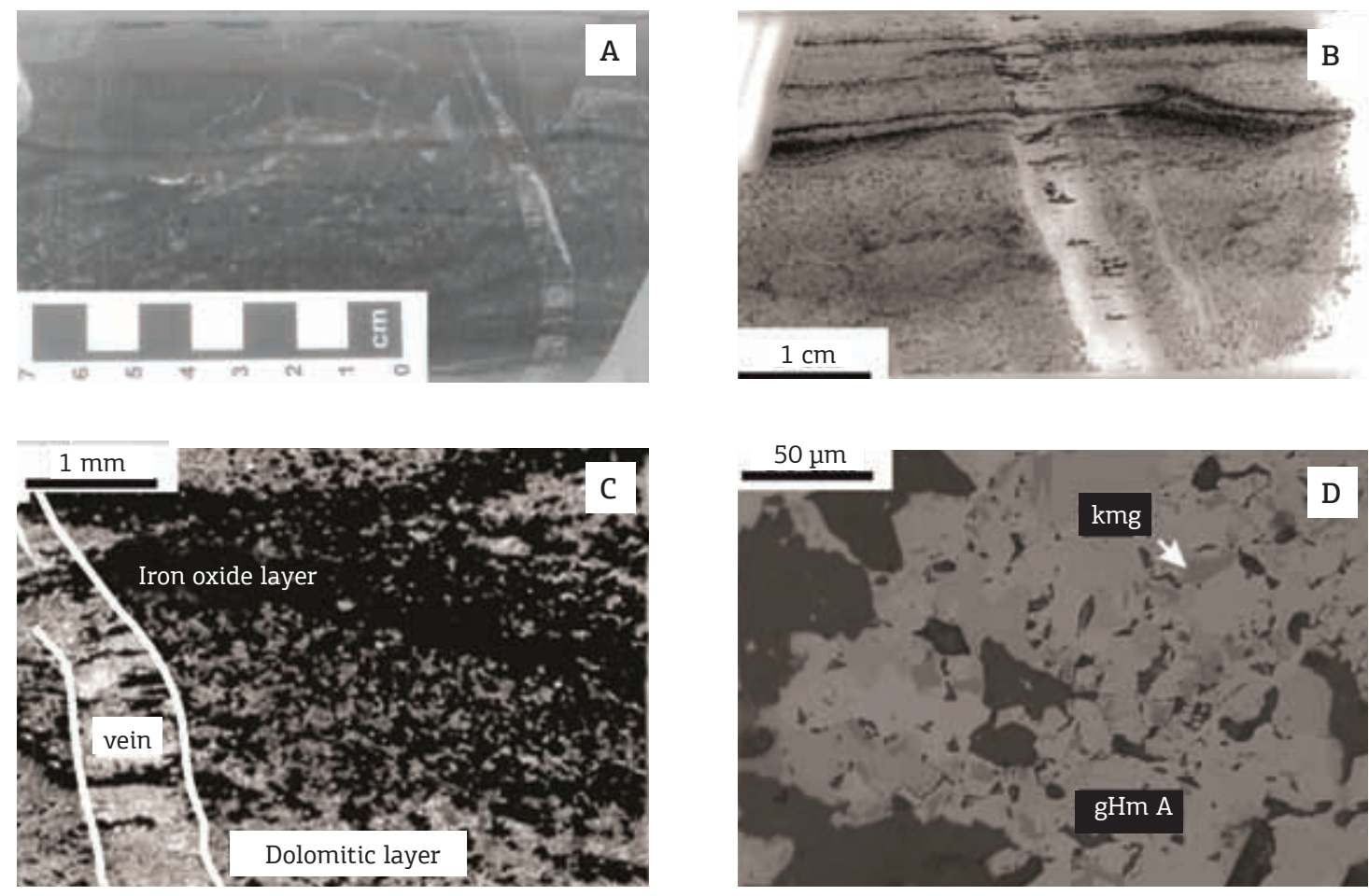

Figure 2. Dolomitic itabirite (DI) from the Esperança Deposit cross-cut by carbonate-quartz-specularite veins. (A) Hand specimen. (B) Thin section. (C) Transmitted light photomicrograph depicting iron oxide and dolomite layers and a crosscutting vein. (D) Reflected light photomicrograph from the iron oxide band exhibiting the complex intergrowth of granular hematite/martite $(\mathrm{gHmA})$ crystals with kenomagnetite $(\mathrm{kmg})$ relicts (dark gray portions indicated by the arrow). 

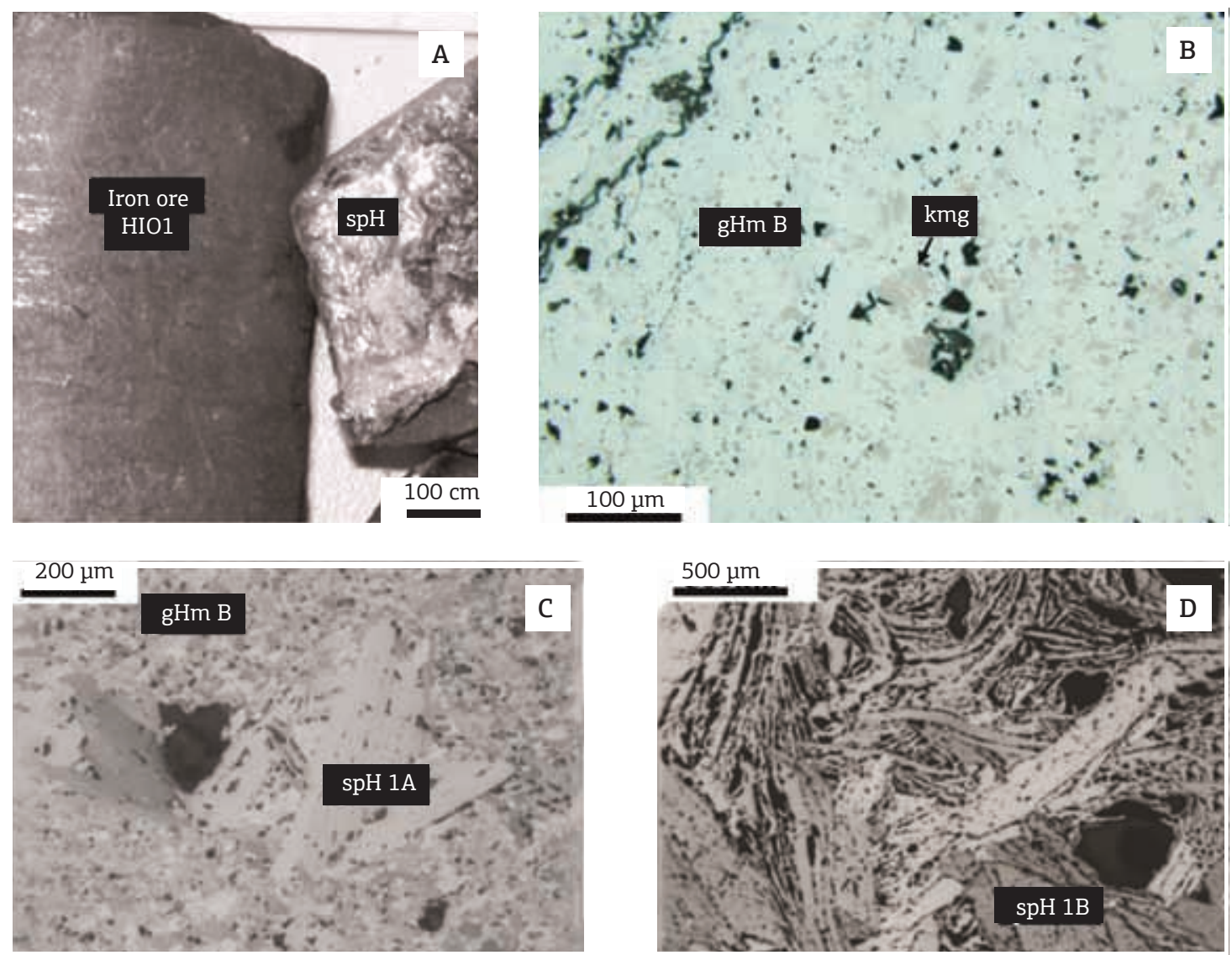

Figure 3. Textural features of high-grade iron ore 1 (HIO1) sample. (A) Hand specimen. (B) Fine grained granular hematite/martite $(\mathrm{gHmB})$ crystals with kenomagnetite $(\mathrm{kmg})$ relics comprising a massive texture with pores and microfractures. Plane polarized reflected light. (C) Platy hematite (spH1A) filling vugs in massive ore. Partially polarized reflected light. (D) Large specularite (spH1B) sheaves grown in irregular-shaped cavity of massive ore. Partially polarized reflected light.
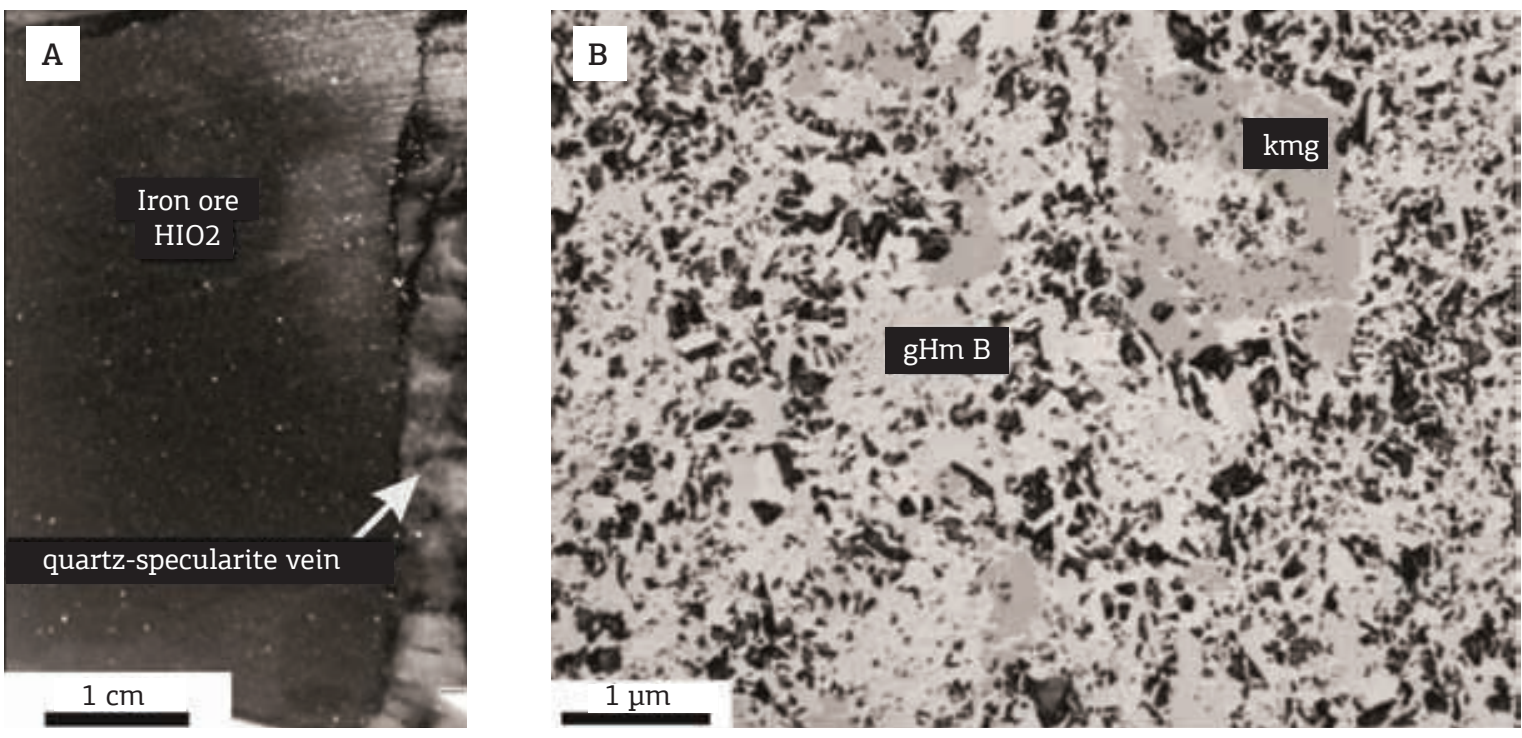

Figure 4. Textural features of high-grade iron ore 2 (HIO2) sample. (A) Hand specimen of massive ore cross-cut by a quartz-specularite vein. (B) Granular hematite/martite (gHmB) aggregates with kenomagnetite (kmg) relics. Plane polarized reflected light. 

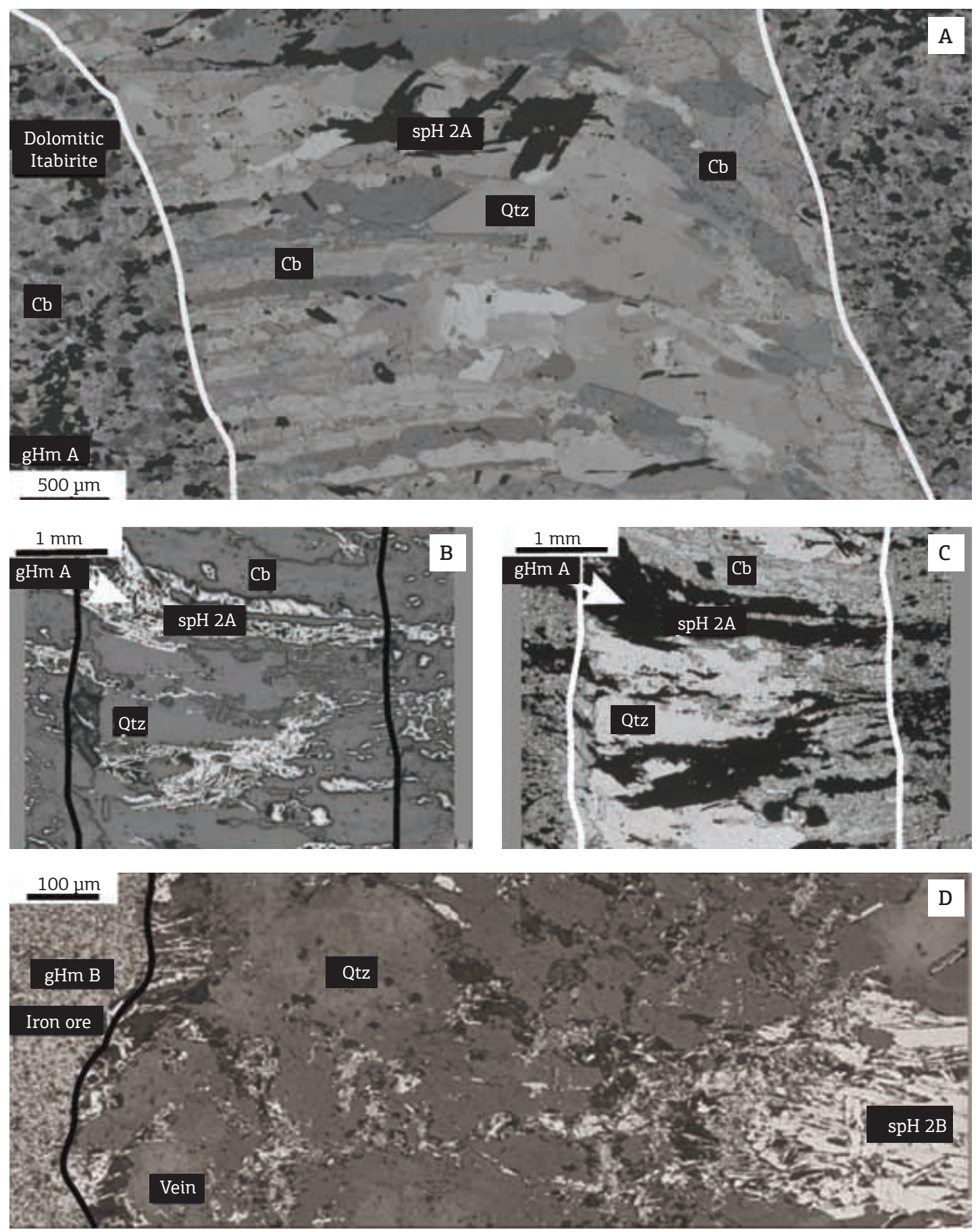

gHmA: granoblastic hematite/martite from dolomitic itabirite; gHmB: granoblastic hematite/martite from high grade iron ore.

Figure 5. (A to C) Asymmetric carbonate (dolomite/calcite), quartz and specularite fibrous composite vein, crosscutting dolomitic itabirite (DI). (A). Fibrous syntaxial carbonate (Cb) and specularite crystals (spH2A) grow from the left wall. Carbonate crystals on the right wall are shorter and less elongated oblique to the wall. Antitaxial quartz crystals (Qtz) and specularite concentrate in the internal sector of the vein as long and wide crystals. Lines highlight the sharp contact between the rock and the vein. (B) Reflected light. (C) Transmitted light. (D) Quartzspecularite asymmetric vein from high-grade iron ore 2 (HIO2) sample. Specularite fibers (spH2B) grow from one wall to the center of the vein. Quartz concentrates as sacaroidal crystals on the opposite wall. 
2. Quartz-specularite vein in high-grade ore also displays asymmetric growth fibers, comprised of elongated specularite $(\mathrm{spH} 2 \mathrm{~B})$ that syntaxially grows from one vein wall towards the other. Sacaroidal quartz concentrates on the opposite wall (Fig. 5D).

\section{RESULTS OF TRACE ELEMENT MICROCHEMISTRY (LA-ICP-MS)}

LA-ICP-MS analyses were performed on different textural types of hematite observed in the studied samples from the Esperança Deposit: granular hematite from DI (gHmA; Fig. 2D) and from high-grade iron ore (gHmB; Figs. 3B and 4B); random specularite plates from sample HIO1 grown in vugs (spH1A; Fig. 3C) and large cavities (spH1B; Fig. 3D); and fibrous specularite from the veins (spH2A, sample DI; Figs. 5A to 5C; spH2B, sample HIO2; Fig. 5D). The obtained results and associated statistical data can be accessed in Appendices 2 and 3.

\section{Dolomitic itabirite}

Figures 6A and 6B display LA-ICP-MS trace element data from granular hematite $(\mathrm{gHmA})$ and vein hosted specularite ( $\mathrm{spH} 2 \mathrm{~A})$. The trace element contents for both iron oxides are generally low (<100 ppm), with the exceptions of Ti ( $\mathrm{gHmA}=211-397 \mathrm{ppm}, \mathrm{ppH} 2 \mathrm{~A}=82-339 \mathrm{ppm})$, $\mathrm{Cr}(\mathrm{gHmA}=78-107 \mathrm{ppm}, \mathrm{spH} 2 \mathrm{~A}=69-93 \mathrm{ppm}), \mathrm{Mg}$ $(\mathrm{gHmA}=912-71273 \mathrm{ppm}, \mathrm{spH} 2 \mathrm{~A}=3.5-1182 \mathrm{ppm})$, $\mathrm{Mn}(\mathrm{gHmA}=337-5885 \mathrm{ppm}, \mathrm{spH} 2 \mathrm{~A}=90-250 \mathrm{ppm})$, $\mathrm{Al}(\mathrm{gHmA}=98-451 \mathrm{ppm}, \mathrm{spH} 2 \mathrm{~A}=73-169 \mathrm{ppm})$, and Si $(\mathrm{gHmA}=1225-1668$ ppm, spH2A = $3888-105443$ ppm). In Fig. 6B, the specularite data were normalized to the average values of the granular hematite. Specularite plates are depleted in most of the analyzed elements, particularly in Mg. Silica exhibits considerably high but variable contents.

\section{High-grade iron ore 1}

Figures 6C and 6D show the composition of granular hematite $(\mathrm{gHmB})$, platy hematite $(\mathrm{spH} 1 \mathrm{~A})$, and specularite (spH1B) crystals. The trace element concentration for the three textural types is also very low, but with concentrations significantly higher than 10 ppm in the following elements: $\mathrm{Na}(\mathrm{gHmB}=25-47$ ppm, spH1A $=2-21$ ppm, spH1B $=22-76$ ppm), Ti $(\mathrm{gHmB}=60-86 \mathrm{ppm}, \mathrm{spH} 1 \mathrm{~A}=212-290 \mathrm{ppm}, \mathrm{spH} 1 \mathrm{~B}=$ $264-455 \mathrm{ppm}), \mathrm{V}(\mathrm{gHmB}=24-32 \mathrm{ppm}, \mathrm{spH} 1 \mathrm{~A}=$ $49-56 \mathrm{ppm}, \mathrm{spH} 1 \mathrm{~B}=48-56 \mathrm{ppm}), \mathrm{Cr}(\mathrm{gHmB}=$ $89-112$ ppm, spH1A $=84-87$ ppm, spH1B = $78-$ $91 \mathrm{ppm}), \mathrm{Mg}(\mathrm{gHmB}=73-166 \mathrm{ppm}, \mathrm{spH} 1 \mathrm{~A}=4-28$ ppm, spH1B = BDL $), \mathrm{Mn}(\mathrm{gHmB}=160-343$ ppm, spH1A = $105-123$ ppm, spH1B = $91-108$ ppm $)$ and $\mathrm{Al}(\mathrm{gHmB}=369-498 \mathrm{ppm}, \mathrm{spH} 1 \mathrm{~A}=88-184 \mathrm{ppm}$, spH1B $=62-178$ ppm) (Fig. 6C). Specularite spH1A and spH1B crystals present very similar contents for most analyzed elements (Figs. 6C and 6D). In Fig. 6D, the data from spH1A and spH1B crystals are normalized to the average values of granular hematite $(\mathrm{gHmB})$. Both spH1A and spH1B are relatively depleted in most of the analyzed elements compared to $\mathrm{gHmB}$, except in $\mathrm{Ti}, \mathrm{V}$, and $\mathrm{Nb}$. Chromium and Ga contents are similar in all three oxide types.

\section{High-grade iron ore 2}

The contents of trace elements obtained for the iron oxides from sample $\mathrm{HIO} 2$ (Figs. 6E and 6F) show a slightly more dispersed pattern than the other two samples, mainly for the specularite crystals (spH2B; Fig. 6E). Only a few elements present concentrations significantly higher than 10 ppm: Ti $(\mathrm{gHmB}=47-77 \mathrm{ppm}, \mathrm{spH} 2 \mathrm{~B}=18-74$ $\mathrm{ppm}), \mathrm{V}(\mathrm{gHmB}=28-47 \mathrm{ppm}, \mathrm{spH} 2 \mathrm{~B}=35-68 \mathrm{ppm})$, $\mathrm{Cr}(\mathrm{gHmB}=71-81 \mathrm{ppm}, \mathrm{spH} 2 \mathrm{~B}=65-93 \mathrm{ppm}), \mathrm{Mg}$ $(\mathrm{gHmB}=43-127 \mathrm{ppm}, \mathrm{spH} 2 \mathrm{~B}=2-120 \mathrm{ppm}), \mathrm{Mn}$ $(\mathrm{gHmB}=100-157 \mathrm{ppm}, \mathrm{spH} 2 \mathrm{~B}=84-811 \mathrm{ppm}), \mathrm{Al}$ $(\mathrm{gHmB}=233-582 \mathrm{ppm}, \mathrm{spH} 2 \mathrm{~B}=53-6148 \mathrm{ppm}), \mathrm{Si}$ $(\mathrm{gHmB}=690-2170 \mathrm{ppm}, \mathrm{spH} 2 \mathrm{~B}=82-12841 \mathrm{ppm})$, and $\mathrm{P}(\mathrm{gHmB}=7-245 \mathrm{ppm}, \mathrm{spH} 2 \mathrm{~B}=34-65 \mathrm{ppm})$. Specularite ( $\mathrm{spH} 2 \mathrm{~B})$ values were normalized to the average contents of granular hematite $(\mathrm{gHmB})$ from this sample (Fig. 6F), revealing a strong depletion of most elements for $\mathrm{spH} 2 \mathrm{~B}$, except for a relative enrichment of $\mathrm{Mn}$ and Si. The contents of Ti, V, Cr, and Ga remained fairly constant.

In order to quantify the chemical differences between the textural types of hematite from the DI and the highgrade iron ore samples, the different analytical results were normalized with respect to the average values determined in the granular hematite (gHmA) from DI (Fig. 7). These values were considered suitable for the normalization once this hematite generation represents the earliest iron oxide available in the studied samples. The patterns of the trace element distribution of granular hematite from the high-grade iron ore samples $(\mathrm{gHmB})$ are very similar to the patterns from $\mathrm{gHmA}$ grains although some distinctions are present. The contents of $\mathrm{V}, \mathrm{Cr}, \mathrm{Al}, \mathrm{Ga}$, $\mathrm{Si}$, As, and $\mathrm{Sb}$ remained constant in both grain types, whereas the elements $\mathrm{Sr}, \mathrm{Mg}$, and $\mathrm{Mn}$ are depleted and $\mathrm{Mo}, \mathrm{Cu}, \mathrm{Bi}$, and $\mathrm{Pb}$ are enriched in the high-grade ore sample (Fig. 7A).

Trace element concentrations are very similar when compared to each other in all specular hematite types 
(Fig. 7B) but strongly depleted when compared with the values from $\mathrm{gHmA}$. $\mathrm{Cr}, \mathrm{Ga}$, and $\mathrm{V}$ contents remain, nevertheless, approximately constant in all analyzed oxide types (Figs. 7 and 8).

\section{Strontium, manganese and magnesium correlations}

$\mathrm{Mg}, \mathrm{Mn}$ and $\mathrm{Sr}$ are major elements that substitute each other in the structure of the carbonates. The LA-ICP-MS analytical results from the hematite crystals from Esperança samples present strong and geochemically significant Pearson linear correlation coefficients for the couples $\mathrm{Sr} / \mathrm{Mg}(0.98)$, $\mathrm{Sr} / \mathrm{Mn}$ (0.96), and $\mathrm{Mg} / \mathrm{Mn}$ (0.99), as illustrated in the binary logarithmic (Fig. 9) and ternary (Fig. 10) plots. From these diagrams, it is evident that granular hematite $(\mathrm{gHmA})$ grains from the DI are significantly richer in $\mathrm{Sr}$, $\mathrm{Mn}$, and $\mathrm{Mg}$ than the iron oxides from both hard ore and veins (Figs. 9 and 10).

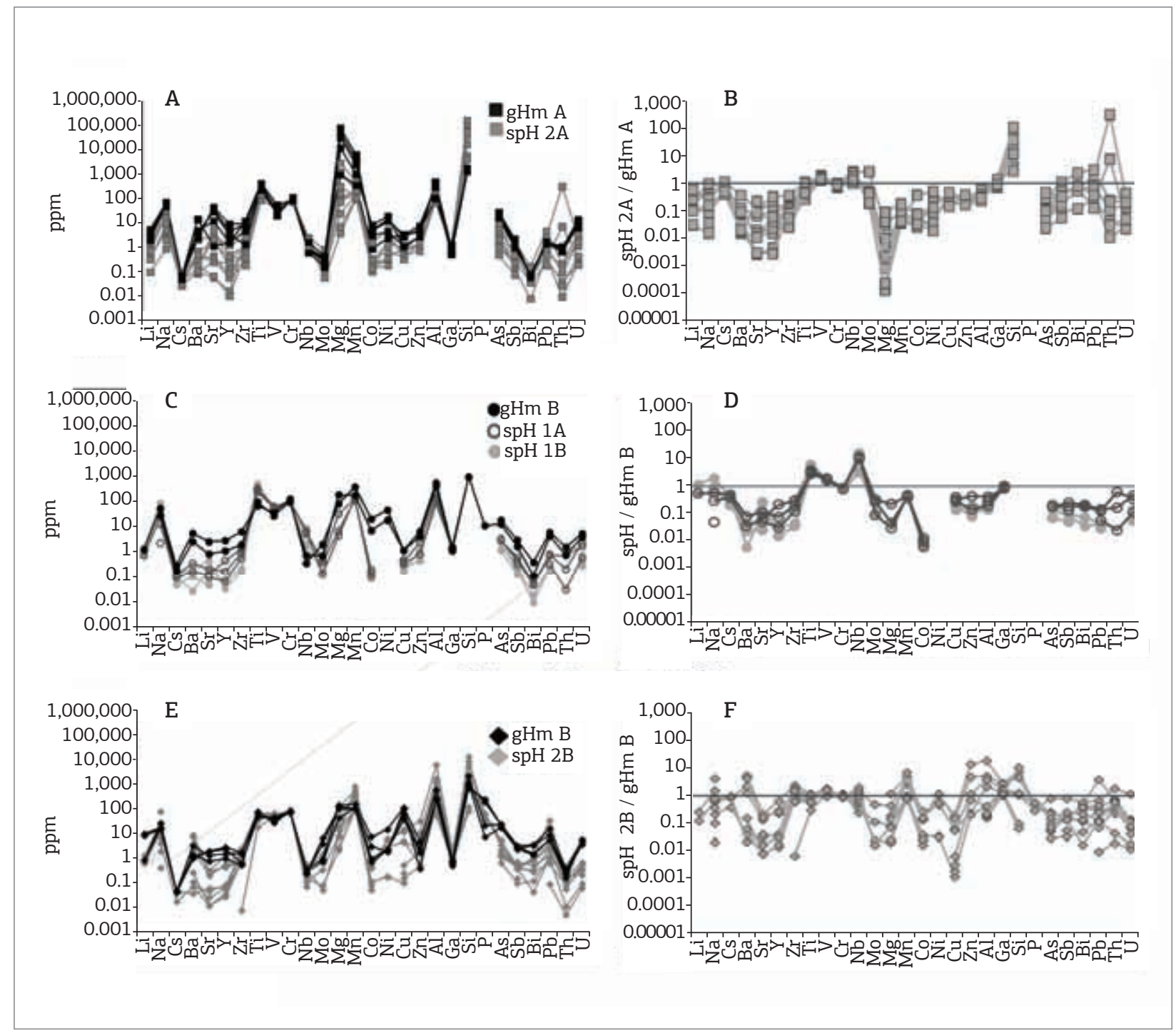

Figure 6. Spider diagrams with the results of trace elements for different iron oxides. Trace elements ordered according to their affinity due the charge density (Z/r). (A) Sample dolomitic itabirite (DI): absolute values for granular hematite $(\mathrm{gHmA})$ grains and vein hosted specular hematite (spH2A). (B) Sample DI: spH2A contents normalized to the average values of gHmA. (C) Sample high-grade iron ore 1 (HIO1): absolute values for granular hematite $(\mathrm{gHmB})$ grains; granular hematite $(\mathrm{gHmB})$ and specular hematite (spH1A and spH1B) grains. specular hematite (spH1A and spH1B). (D) Sample HIO1: spH1A and spH1B contents normalized to the average values of gHmB. (E) Sample high-grade iron ore 2 (HIO2): absolute values for granular hematite (gHmB) and vein hosted specularite (spH2B). (F) Sample HIO2: spH2B contents normalized to the average values of gHmB. 
There is a progressive decrease in the relative contents of $\mathrm{Mg}$ and $\mathrm{Sr}$ from the $\mathrm{gHmA}$ grains to high-grade $\mathrm{gHmB}$ and then to high-grade iron ore specularite ( $\mathrm{spH} 1 \mathrm{~A}$, spH1B, and spH2B). In contrast, the behavior presented by $\mathrm{Mn}$ shows a relative increase from the granular $\mathrm{Hm}$ to the younger specularite plates found in the high-grade ore sample (spH1A, spH1B, and $\mathrm{spH} 2 \mathrm{~B})$. In the $\mathrm{spH} 2 \mathrm{~A}$ platelets from itabirite, on the other hand, the contents of $\mathrm{Mg}, \mathrm{Mn}$, and $\mathrm{Sr}$ exhibit stronger variations than the other hematite generations (Fig. 10).

\section{Titanium, chromium and vanadium mobility}

The narrow ranges of values for $\mathrm{Cr}$ and $\mathrm{V}$ suggest that these elements behaved largely immobile during the formation of the different textural types of hematite (Fig. 8).
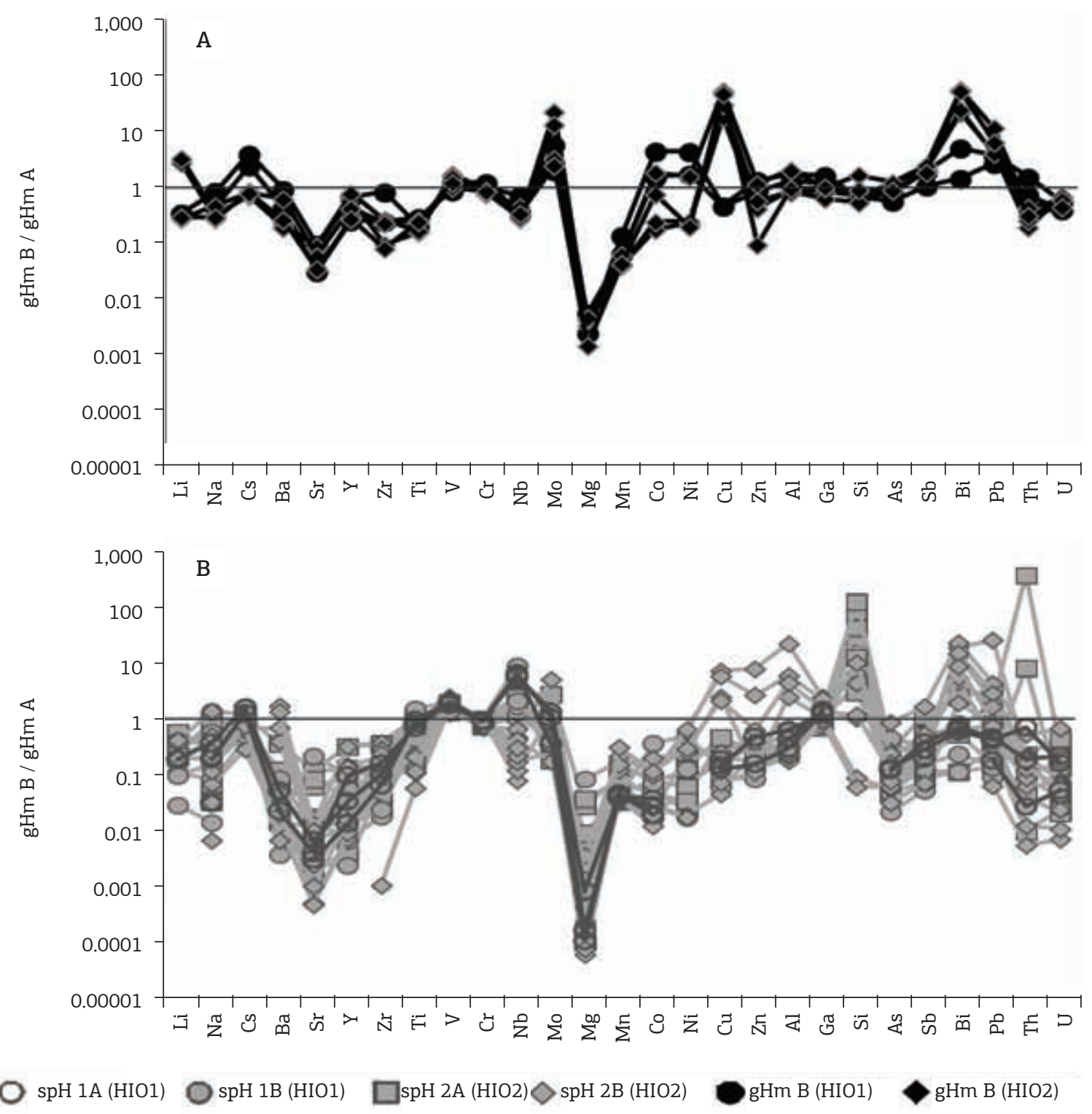

Figure 7. Spider diagrams of the analyzed contents normalized to the average values of gHmA. (A) Granular hematite from high-grade iron ore (gHmB). (B) Specularite (spH1A, 1B, 2A and 2B). 


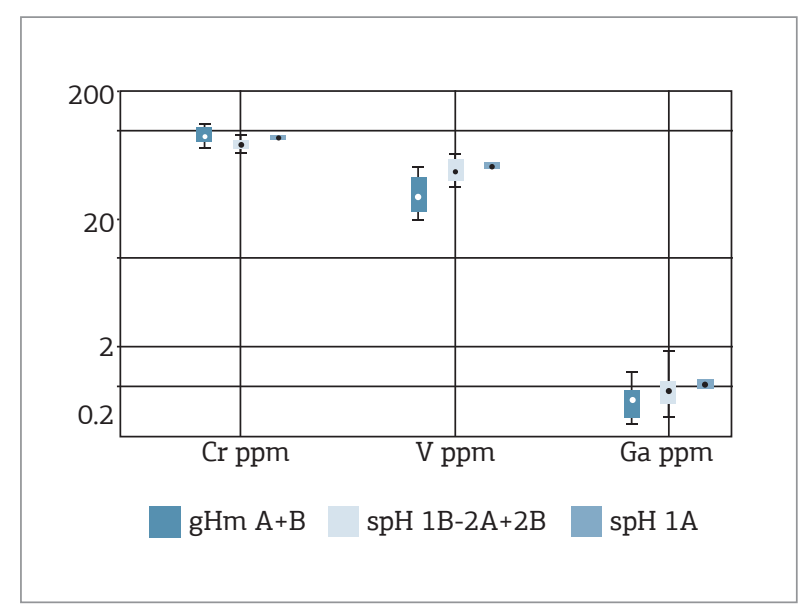

Figure 8. Box diagram showing the small variations of $\mathrm{Cr}, \mathrm{V}$, and $\mathrm{Ga}$ contents in all iron oxides. Whisker: maximum and minimum; box: 50\% of data (Q1-Q3); line: median; circle: mean.

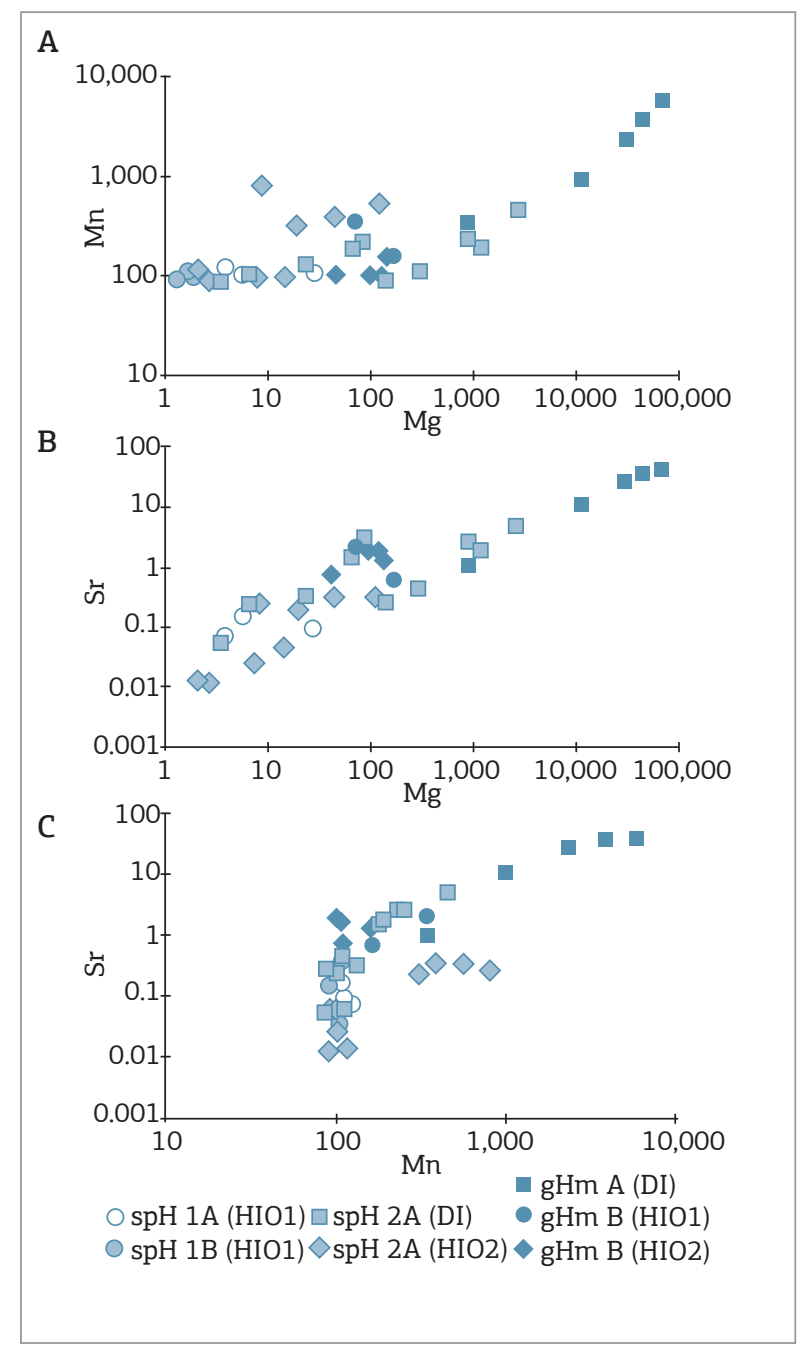

Figure 9. Binary logarithmic plots correlating $\mathrm{Mg}, \mathrm{Mn}$, and $\mathrm{Sr}$ for iron oxides. (A) $\mathrm{Mn}$ versus $\mathrm{Mg}$ (0.99). (B) $\mathrm{Sr}$ versus $\mathrm{Mg}$ (0.98). (C) Sr versus $\mathrm{Mn}$ (0.96).
On the other hand, the $\mathrm{Ti}$ contents present a relative variation in comparison with $\mathrm{Cr}$ and $\mathrm{V}$ as indicated in Fig. 11. This relation is represented by the trajectories I and II in Fig. 11, which indicate the relative decreasing values of $\mathrm{Ti}$ from $\mathrm{gHmA}$ to $\mathrm{gHmB}$ (trajectory I) and from spH1A and $1 \mathrm{~B}$ to $\mathrm{spH} 2 \mathrm{~A}$ and $2 \mathrm{~B}$ (trajectory II).

\section{Rare earth elements and yttrium behavior}

The REE-Y contents in the iron oxides were normalized with respect to Post Archean Average Shale (PAAS; McLennan 1989; Fig. 12). The $\Sigma$ REE values (Tabs. 1 to 4) are very low for all analyzed iron oxides, but higher for granular hematite grains (between 3 and $15 \mathrm{ppm}$ ) than for the younger specularite plates $(<5 \mathrm{ppm})$.

The REE-Y spidergrams of granular hematite crystals from DI (gHmA) are very similar to those for BIF whole rock analyses reported by Spier et al. (2007) from the Quadrilátero Ferrífero (Fig. 12). They show generally low light/heavy rare earth elements (LREE/HREE) ratio with $(\mathrm{La} / \mathrm{Yb})_{\text {PAAS }}$ and $(\mathrm{Sm} / \mathrm{Yb})_{\text {PAAS }}$ varying from 0.19 to 1.13 and from 0.18 to 0.55 , respectively, and present positive anomalies of both $\mathrm{Eu}(0.90-2.72)$ and $\mathrm{Y}(1.43-3.48$; Table 1). The granular hematite from high-grade iron ore $(\mathrm{gHmB})$ present higher values for $(\mathrm{La} / \mathrm{Yb})_{\text {PAAS }}(1.5-$ $10.25)$ and $(\mathrm{Sm} / \mathrm{Yb})_{\text {PAAS }}(0.62-3.25)$; lower Eu anomaly $(1.0-1.9)$ and nearly no $\mathrm{Y}$ anomaly $(0.8-1.2$; Tab. 1$)$. Specularite crystals present very low $\Sigma$ REE with several

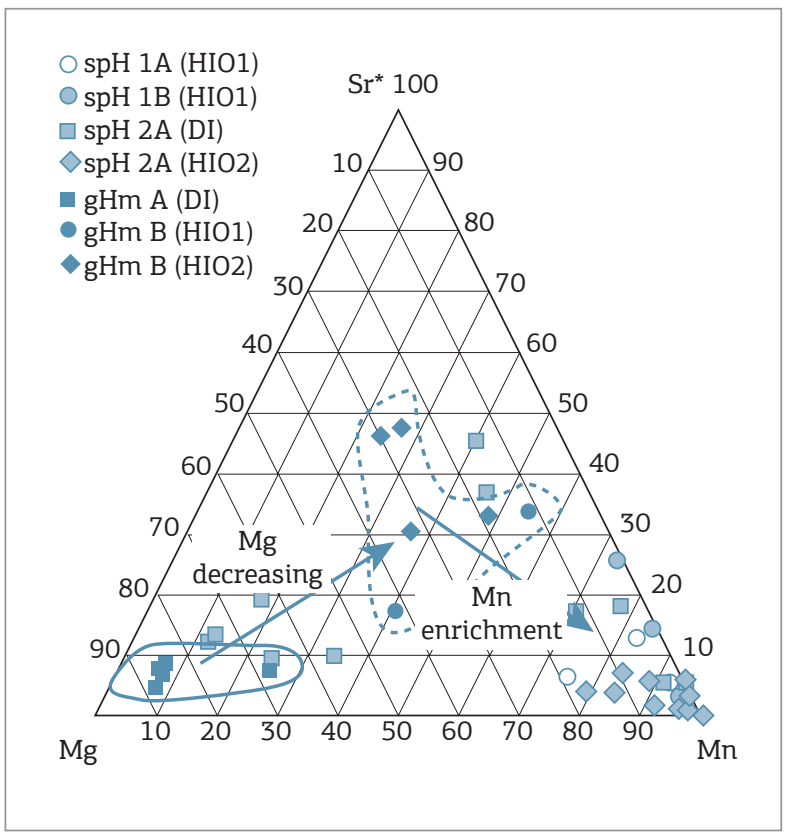

Figure 10. Ternary diagram of the relative concentration (ppm) of $\mathrm{Sr}^{*} 100, \mathrm{Mg}$, and $\mathrm{Mn}$ from the different textural types of hematite. 
single analytic values below the detection limit (BDL), preventing the calculation of $\mathrm{Eu}$ and $\mathrm{Y}$ anomalies for these minerals (Tabs. 2 to 4 ).

Most of the granular hematite $(\mathrm{gHmA})$ and specularite $(\mathrm{spH} 2 \mathrm{~A})$ from the DI sample show true negative Ce anomaly (sensu Bau \& Dulski 1996), whereas iron oxides from high-grade iron ore show nearly positive or no Ce anomalies (Fig. 13).

In a CHArge-and-RAdius-Controlled (CHARAC) geochemical system, a twin pair element with similar charge and radius, like in the case of Y-Ho, should present a consistent behavior and preserve their chondritic ratio, $24<\mathrm{Y} / \mathrm{Ho}<34$ (Bau 1996). However, the primitive relationship between these two elements is not expected in aqueous solution due to their fractionation controlled by chemical interactions with the fluid leading to higher Y/Ho ratios (Minami et al. 1998). Fractionation of these elements in seawater occurs most probably by scavenging of Ho by particulate matter, resulting in the hyperchondritic values of 44 to 74 as found in modern oceans, which is higher than for shales ( 27 ; Bau 1996; Nozaki et al. 1997). Early Paleoproterozoic BIFs, considered to reflect chemical conditions of ancient oceans, have positive $\mathrm{Y}$ anomalies and an average $\mathrm{Y} / \mathrm{Ho}$ ratio of 39 (Planavsky et al. 2010).

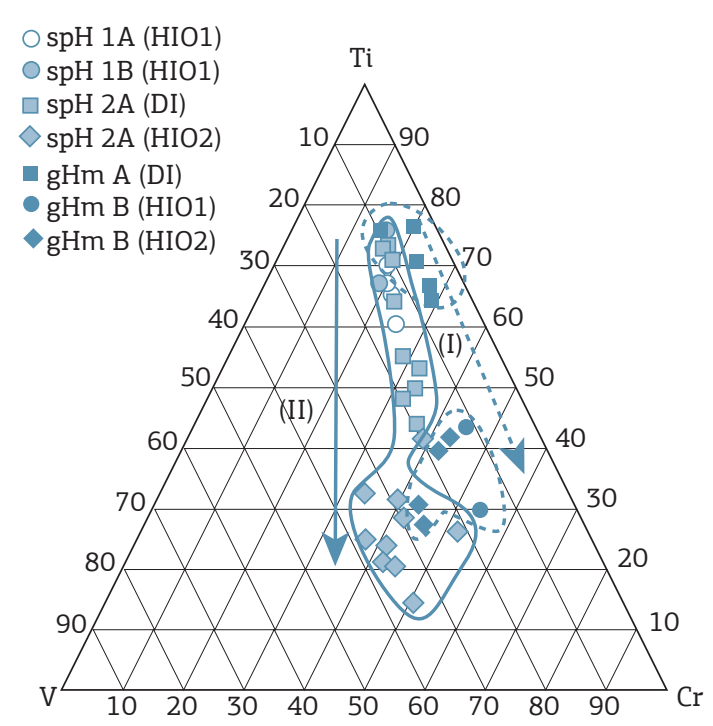

Trajectory I: relative decreasing values of Ti from gHmA to gHmB; Trajectory II: relative decreasing values of $\mathrm{Ti}$ from spH1A and $1 \mathrm{~B}$ to spH2A and 2B.

Figure 11. Vanadium, Chromium and Titanium relative concentration (ppm) ternary diagram presenting trends of mobility of $\mathrm{Ti}$ in al different iron oxide generations.
The $\mathrm{Y} / \mathrm{Ho}$ ratios were calculated for all iron oxides from the Esperança samples. The results are plotted in a Y versus Y/Ho diagram and compared to chondritic (CHARAC) and seawater value ranges (Fig. 14). Granular hematite from DI (gHmA) exhibit Y/Ho ratios $(38-77)$ near the seawater field (Fig. 14). Granular hematite from high-grade iron ore $(\mathrm{gHmB})$, HIO1 $(22-23)$ and HIO2 $(20-30)$ present $\mathrm{Y} / \mathrm{Ho}$ ratios within or close to the CHARAC field, whereas spH2A (6 - 34) has near-chondritic or subchondritic ratios. Specularite from high-grade iron ore $(\mathrm{spH} 1 \mathrm{~A}=$ 18 - 47; spH1B = 7; and spH2B = 9-24) shows a widespread pattern of $\mathrm{Y} / \mathrm{Ho}$ ratios, from near chondritic to subchondritic values.

A

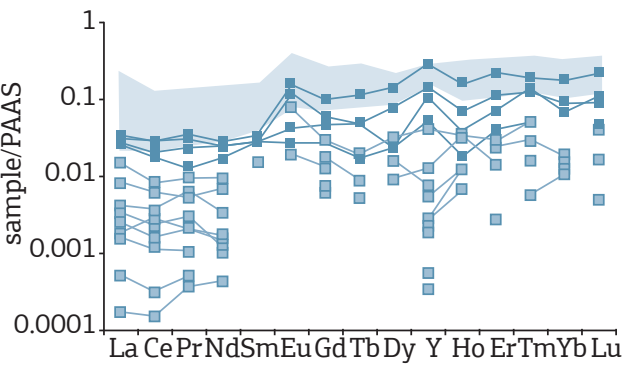

B

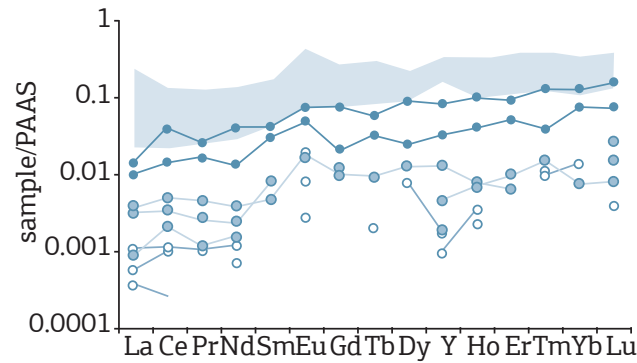

C

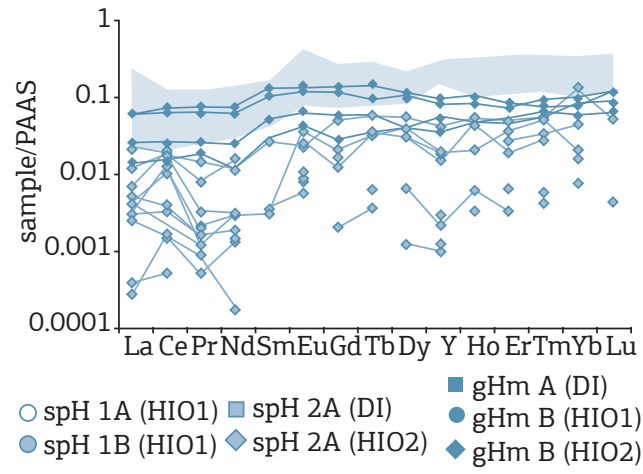

Figure 12. The rare earth elements and yttrium spider diagram PAAS normalized (McLennan 1989) for the different generations of iron oxide: (A) Dolomitic itabirite. (B) High-grade iron ore 1 (HIO1). (C) Highgrade iron ore 2 (HIO2). Shaded light blue are the whole rock geochemical data from Spier et al. (2007) for dolomitic itabirite from the Águas Claras deposit. 


\section{DISCUSSION}

Textural relationships in the samples from the Esperança Deposit indicate that magnetite is the oldest iron oxide species. Magnetite forms relics in granular hematite/ martite aggregates (Figs. 2D, 3B and 4B) in both DI $(\mathrm{gHmA})$ and high-grade iron ore $(\mathrm{gHmB})$. Similar to the ores from other deposits located in the Quadrilátero Ferrífero (Hackspacher 1979; Rosière 1981; Rosière \& Chemale 1991), magnetite appears commonly as the pink-brown kenomagnetite (Kullerud et al. 1969; Morris 1980; Rosière 1981). Kenomagnetite is a partially oxidized, $\mathrm{Fe}^{2+}$-deficient oxide that is commonly associated with iron enrichment and the formation of high-grade ore bodies (Rosière et al. 2008). The progressive oxidation of magnetite leads to the formation of kenomagnetite/maghemite and hematite (martite). They comprise an aggregate of crystallographically defective grains with free $\mathrm{Fe}^{2+}$ sites (Kullerud et al. 1969) that are complex intergrowths and exhibit tiny inclusions and micropores as

Table 1. Rare earth elements and yttrium data obtained by LA-ICP-MS for granular hematite from samples dolomitic itabirite, high-grade iron ore 1 , and high-grade iron ore 2.

\begin{tabular}{|c|c|c|c|c|c|c|c|c|c|c|c|}
\hline \multirow{2}{*}{ Sample } & \multicolumn{5}{|c|}{ DI (gHmA) } & \multicolumn{2}{|c|}{ HIO1 (gHmB) } & \multicolumn{4}{|c|}{ HIO2 (gHmB) } \\
\hline & 1 & 2 & 3 & 4 & 5 & 1 & 2 & 3 & 4 & 5 & 6 \\
\hline $\mathrm{La}$ & 1.374 & 1.048 & 1.158 & 1.287 & 1.498 & 0.551 & 0.387 & 2.430 & 2.420 & 1.010 & 0.558 \\
\hline $\mathrm{Ce}$ & 2.390 & 1.478 & 1.710 & 2.350 & 2.009 & 3.200 & 1.144 & 5.350 & 6.060 & 2.150 & 1.300 \\
\hline $\operatorname{Pr}$ & 0.283 & 0.122 & 0.221 & 0.318 & 0.233 & 0.236 & 0.149 & 0.587 & 0.693 & 0.235 & 0.174 \\
\hline $\mathrm{Nd}$ & 0.930 & 0.628 & 0.880 & 1.000 & 0.515 & 1.410 & 0.465 & 2.150 & 2.620 & 0.891 & 0.414 \\
\hline $\mathrm{Sm}$ & 0.189 & 0.163 & 0.167 & 0.200 & 0.106 & 0.234 & 0.176 & 0.623 & 0.766 & 0.309 & 0.168 \\
\hline $\mathrm{Eu}$ & 0.174 & 0.031 & 0.049 & 0.142 & 0.054 & 0.082 & 0.054 & 0.139 & 0.154 & 0.074 & 0.049 \\
\hline $\mathrm{Gd}$ & 0.480 & 0.132 & 0.238 & 0.307 & 0.121 & 0.355 & 0.098 & 0.593 & 0.679 & 0.277 & 0.140 \\
\hline $\mathrm{Tb}$ & 0.094 & 0.014 & 0.040 & 0.038 & 0.019 & 0.046 & 0.026 & 0.078 & 0.116 & 0.047 & 0.029 \\
\hline Dy & 0.720 & 0.129 & 0.114 & 0.390 & 0.177 & 0.433 & 0.117 & 0.513 & 0.570 & 0.194 & 0.199 \\
\hline Y & 8.560 & 1.450 & 3.020 & 4.200 & 1.492 & 2.360 & 0.902 & 2.330 & 2.790 & 1.510 & 0.980 \\
\hline Ho & 0.163 & 0.019 & 0.042 & 0.076 & 0.039 & 0.103 & 0.041 & 0.087 & 0.109 & 0.051 & 0.048 \\
\hline Er & 0.675 & 0.124 & 0.216 & 0.348 & 0.166 & 0.267 & 0.149 & 0.219 & 0.253 & 0.156 & 0.135 \\
\hline $\mathrm{Tm}$ & 0.080 & 0.022 & 0.060 & 0.053 & 0.011 & 0.055 & 0.016 & 0.038 & 0.033 & 0.023 & 0.028 \\
\hline $\mathrm{Yb}$ & 0.530 & BDL & 0.261 & 0.210 & 0.098 & 0.376 & 0.218 & 0.289 & 0.236 & 0.246 & 0.174 \\
\hline $\mathrm{Lu}$ & 0.105 & 0.022 & 0.043 & 0.050 & 0.021 & 0.071 & 0.033 & 0.052 & 0.055 & 0.039 & 0.030 \\
\hline$\Sigma \mathrm{REE}$ & 8.187 & 3.931 & 5.199 & 6.769 & 5.068 & 7.419 & 3.073 & 13.149 & 14.765 & 5.702 & 3.445 \\
\hline $\mathrm{La} / \mathrm{Yb}_{\mathrm{PAAS}}$ & 0.191 & & 0.328 & 0.452 & 1.128 & 1.465 & 1.775 & 8.408 & 10.254 & 4.106 & 3.207 \\
\hline $\mathrm{Sm} / \mathrm{Yb}_{\mathrm{PAAS}}$ & 0.181 & & 0.325 & 0.484 & 0.550 & 0.622 & 0.807 & 2.156 & 3.246 & 1.256 & 0.966 \\
\hline $\mathrm{Pr} / \mathrm{Pr}^{*}{ }_{\mathrm{PAAS}}$ & 1.116 & 0.745 & 1.055 & 1.220 & 1.305 & 0.654 & 1.202 & 1.018 & 1.023 & 0.999 & 1.381 \\
\hline $\mathrm{Eu} / \mathrm{Eu}_{\mathrm{PAAS}}^{*}$ & 2.720 & 0.995 & 1.157 & 2.698 & 2.245 & 1.340 & 1.936 & 1.077 & 1.006 & 1.191 & 1.505 \\
\hline $\mathrm{Y} / \mathrm{Y}^{*}{ }_{\mathrm{PAAS}}$ & 1.993 & 2.342 & 3.481 & 1.946 & 1.432 & 0.891 & 1.039 & 0.880 & 0.893 & 1.214 & 0.800 \\
\hline $\mathrm{Ce} / \mathrm{Ce}^{*}{ }_{\text {PAAS }}$ & 0.883 & 0.900 & 0.776 & 0.847 & 0.769 & 1.954 & 1.064 & 1.033 & 1.074 & 1.018 & 0.952 \\
\hline $\mathrm{Y} / \mathrm{Ho}$ & 52.515 & 76.720 & 71.905 & 55.263 & 38.256 & 22.913 & 22.000 & 26.782 & 25.596 & 29.783 & 20.417 \\
\hline
\end{tabular}

DI: dolomitic itabirite; gHmA: granoblastic hematite/martite from dolomitic itabirite; HIO1: high-grade iron ore 1; gHmB: granoblastic hematite/martite from high grade iron ore; HIO2: high-grade iron ore 2; REE: rare earth elements; PAAS: Post Archean Average Shale. 
well as lower reflectivity. The large numbers of $\mathrm{Fe}^{2+}$ free sites in granular hematite (martite) host the high concentration of cations such as $\mathrm{Mn}, \mathrm{Mg}, \mathrm{Sr}, \mathrm{Ti}, \mathrm{Cr}$, and V with similar charge density.

Comparison of trace element contents of the granular hematite/martite grains from DI ( $\mathrm{gHmA}$ ) and from high-grade iron ore samples $(\mathrm{gHmB})$ reveals significant variations, suggesting a geochemical alteration trend associated with the iron enrichment process. The contents of
$\mathrm{V}, \mathrm{Cr}, \mathrm{Al}, \mathrm{Ga}, \mathrm{Si}, \mathrm{As}$, and $\mathrm{Sb}$ remain constant (immobile), whereas $\mathrm{Sr}, \mathrm{Mg}$, and $\mathrm{Mn}$ become fractionated and relatively depleted and $\mathrm{Mo}, \mathrm{Cu}, \mathrm{Bi}$, and $\mathrm{Pb}$ are relatively enriched.

Trace elements spidergrams of the four discriminated types of specularite (iron ore cavities: spH1A and $\mathrm{spH} 1 \mathrm{~B}$; DI vein: spH2A; and iron ore vein: $\mathrm{spH} 2 \mathrm{~B}$ ) display similar patterns with depletion in nearly all elements when compared with granular hematite ( $\mathrm{gHmA}$ and $\mathrm{gHmB}$ ) from itabirite and high-grade iron ore. Platy hematite crystals in veins and vugs as well as in

Table 2. Rare earth elements and yttrium data obtained by LA-ICP-MS for specularite from sample high-grade iron ore 1 .

\begin{tabular}{|c|c|c|c|c|c|c|}
\hline \multirow{2}{*}{ Sample } & \multicolumn{6}{|c|}{ HIO1 } \\
\hline & spH1A-1 & spH1A-2 & spH1A-3 & spH1B-1 & spH1B-2 & spH1B-3 \\
\hline $\mathrm{La}$ & 0.146 & 0.034 & 0.122 & 0.014 & 0.041 & 0.022 \\
\hline $\mathrm{Ce}$ & 0.394 & 0.168 & 0.273 & 0.021 & 0.090 & 0.080 \\
\hline $\operatorname{Pr}$ & 0.040 & 0.010 & 0.024 & BDL & 0.009 & BDL \\
\hline $\mathrm{Nd}$ & 0.132 & 0.055 & 0.081 & BDL & 0.041 & 0.024 \\
\hline Sm & 0.026 & BDL & 0.046 & BDL & BDL & BDL \\
\hline $\mathrm{Eu}$ & 0.019 & $\mathrm{BDL}$ & BDL & 0.021 & 0.003 & 0.009 \\
\hline Gd & 0.047 & BDL & 0.058 & BDL & BDL & BDL \\
\hline $\mathrm{Tb}$ & 0.007 & BDL & BDL & BDL & 0.002 & BDL \\
\hline Dy & 0.061 & BDL & BDL & BDL & BDL & 0.037 \\
\hline Y & 0.364 & 0.052 & 0.127 & BDL & 0.026 & 0.050 \\
\hline Ho & 0.008 & BDL & 0.007 & 0.002 & 0.004 & BDL \\
\hline $\mathrm{Er}$ & 0.018 & BDL & 0.028 & BDL & BDL & BDL \\
\hline $\mathrm{Tm}$ & BDL & 0.006 & 0.006 & 0.004 & BDL & 0.005 \\
\hline $\mathrm{Yb}$ & BDL & 0.021 & BDL & 0.038 & BDL & BDL \\
\hline $\mathrm{Lu}$ & 0.012 & 0.004 & 0.007 & BDL & BDL & 0.002 \\
\hline$\Sigma \mathrm{REE}$ & 0.910 & 0.298 & 0.652 & 0.100 & 0.190 & 0.178 \\
\hline $\mathrm{La} / \mathrm{Yb}_{\mathrm{PAAS}}$ & & 1.638 & & 0.368 & & \\
\hline $\mathrm{Sm} / \mathrm{Yb}_{\mathrm{PAAS}}$ & & 0.000 & & 0.000 & & \\
\hline $\mathrm{Pr} / \mathrm{Pr}^{*}{ }_{\text {PAAS }}$ & 1.030 & 0.613 & 0.934 & & 0.890 & \\
\hline $\mathrm{Eu} / \mathrm{Eu}^{*}{ }_{\mathrm{PAAS}}$ & 2.586 & & 0.000 & & & \\
\hline $\mathrm{Y} / \mathrm{Y}^{*}{ }_{\mathrm{PAAS}}$ & 1.331 & & & & & \\
\hline $\mathrm{Ce} / \mathrm{Ce}^{*}{ }_{\text {PAAS }}$ & 1.182 & 2.065 & 1.160 & 1.433 & 1.065 & 3.555 \\
\hline $\mathrm{Y} / \mathrm{Ho}$ & 46.667 & & 18.406 & & 7.343 & \\
\hline
\end{tabular}

HIO1: high-grade iron ore 1; spH1A: large platy hematite (specularite) found in vugs in high grade iron ore 1; spH1B: elongated coarse platy crystals (specularite) filling open spaces or fractures in high grade iron ore 1 (the numbers are for different crystals analysed); REE: rare earth elements; PAAS: Post Archean Average Shale. 
all schistose ore types are the product of solution-precipitation processes (Rosière et al. 2013b). The present results indicate a high dilution of all elements in the newly precipitated grains although some distinctive characteristics are still noticeable for each platy hematite and schistose ore types:

- Specularite crystals found in cavities (spH1A and spH1B) have similar elemental distribution than vein specularite (spH2A and 2B), but with slightly higher contents of Ti and $\mathrm{Nb}$ indicating they were precipitated from very similar fluids.
Specularite crystals from the carbonate-quartz vein (spH2A) in DI exhibit Cs, Ti, V, Cr, Nb, and Ga contents similar to $\mathrm{gHmA}$ indicating an affinity of the new vein crystals with the host rock.

- Mn contents in the specularite crystals from the vein in high-grade iron ore $(\mathrm{spH} 2 \mathrm{~B})$ are relatively higher than in the $\mathrm{spH} 2 \mathrm{~A}$ plates (Fig. 7). Its presence and concentration is dependent on two main factors: the availability of this element in the fluid and the variation in the oxidation

Table 3. Rare earth elements and yttrium data obtained by LA-ICP-MS for specularite crystals from the vein that cross-cut sample dolomitic itabirite.

\begin{tabular}{|c|c|c|c|c|c|c|c|c|c|c|c|}
\hline \multirow{2}{*}{ Sample } & \multicolumn{11}{|c|}{ DI (spH2A) } \\
\hline & 1 & 2 & 3 & 4 & 5 & 6 & 7 & 8 & 9 & 10 & 11 \\
\hline $\mathrm{La}$ & 0.905 & 0.072 & 0.584 & 0.327 & 0.020 & 0.096 & 0.063 & BDL & 0.007 & 0.164 & 0.130 \\
\hline $\mathrm{Ce}$ & 1.178 & 0.236 & 0.696 & 0.511 & 0.026 & 0.135 & 0.096 & 0.025 & 0.013 & 0.302 & 0.181 \\
\hline $\operatorname{Pr}$ & 0.099 & 0.019 & 0.088 & 0.048 & 0.005 & 0.019 & 0.010 & BDL & 0.003 & 0.060 & 0.027 \\
\hline $\mathrm{Nd}$ & 0.324 & 0.049 & 0.330 & 0.247 & $\mathrm{BDL}$ & 0.058 & BDL & 0.047 & 0.015 & 0.116 & 0.038 \\
\hline Sm & 0.096 & BDL & BDL & BDL & BDL & BDL & 0.087 & $\mathrm{BDL}$ & BDL & BDL & BDL \\
\hline $\mathrm{Eu}$ & 0.024 & $\mathrm{BDL}$ & BDL & 0.091 & BDL & 0.022 & BDL & $\mathrm{BDL}$ & $\mathrm{BDL}$ & BDL & BDL \\
\hline Gd & 0.022 & BDL & 0.083 & 0.141 & BDL & 0.063 & 0.031 & $\mathrm{BDL}$ & BDL & BDL & 0.036 \\
\hline $\mathrm{Tb}$ & BDL & BDL & 0.007 & 0.016 & $\mathrm{BDL}$ & BDL & BDL & BDL & 0.004 & BDL & BDL \\
\hline Dy & BDL & BDL & BDL & 0.158 & $\mathrm{BDL}$ & BDL & $\mathrm{BDL}$ & BDL & BDL & 0.044 & 0.078 \\
\hline Y & 0.488 & 0.068 & 0.338 & 1.180 & 0.053 & 0.081 & 0.150 & 0.015 & 0.009 & 0.356 & 0.219 \\
\hline Ho & 0.019 & 0.007 & 0.037 & 0.034 & BDL & 0.013 & 0.013 & BDL & BDL & BDL & BDL \\
\hline $\mathrm{Er}$ & 0.069 & BDL & 0.043 & 0.090 & BDL & BDL & BDL & $\mathrm{BDL}$ & 0.008 & 0.072 & BDL \\
\hline $\mathrm{Tm}$ & 0.022 & 0.002 & BDL & 0.022 & BDL & 0.007 & BDL & BDL & BDL & 0.012 & 0.007 \\
\hline $\mathrm{Yb}$ & 0.091 & 0.031 & 0.059 & BDL & BDL & BDL & 0.037 & BDL & BDL & 0.048 & BDL \\
\hline $\mathrm{Lu}$ & 0.020 & BDL & BDL & BDL & 0.018 & 0.008 & BDL & BDL & 0.002 & BDL & BDL \\
\hline$\Sigma \mathrm{REE}$ & 2.869 & 0.417 & 1.927 & 1.685 & 0.069 & 0.420 & 0.337 & 0.072 & 0.052 & 0.818 & 0.497 \\
\hline $\mathrm{La} / \mathrm{Yb}_{\text {PAAS }}$ & 0.734 & 0.171 & 0.731 & & & & 0.126 & & & 0.252 & \\
\hline $\mathrm{Sm} / \mathrm{Yb}_{\mathrm{PAAS}}$ & 0.536 & 0.000 & 0.000 & & & & 1.195 & & & 0.000 & \\
\hline $\operatorname{Pr} / \operatorname{Pr}^{*}{ }_{\text {PAAS }}^{*}$ & 0.921 & 0.981 & 1.079 & 0.793 & 3.297 & 1.263 & 1.803 & & 1.247 & 1.883 & 1.801 \\
\hline $\mathrm{Eu} / \mathrm{Eu}^{*}{ }_{\text {PAAS }}$ & 2.459 & & & & & & 0.000 & & & & \\
\hline \multicolumn{12}{|l|}{$\mathrm{Y} / \mathrm{Y}_{\text {PAAS }}^{*}$} \\
\hline $\mathrm{Ce} / \mathrm{Ce}^{*}{ }_{\text {PAAS }}$ & 0.848 & 1.465 & 0.692 & 0.917 & 0.609 & 0.727 & 0.881 & & 0.572 & 0.684 & 0.704 \\
\hline $\mathrm{Y} / \mathrm{Ho}$ & 25.417 & 9.444 & 9.135 & 34.706 & & 6.231 & 11.538 & & & & \\
\hline
\end{tabular}

DI: dolomitic itabirite; spH2A: thin specularite plates from the carbonate-quartz-specularite vein in dolomitic itabirite; BDL: below the detection limit; REE: rare earth elements; PAAS: Post Archean Average Shale. 
state. Mn must have been mobilized from the carbonates of the itabirite occupying octahedral sites in the new precipitated specularite platelets as discussed next.

- The relatively elevated Si content found in some specularite crystals from the veins $(\mathrm{spH} 2 \mathrm{~A}$ and $\mathrm{spH} 2 \mathrm{~B}$; Figs. $6 \mathrm{~A}$ and $6 \mathrm{~B}$ ) is still subject of debate. Possibly, it could represent submicroscopic quartz inclusions or intergrowths that co-precipitated with hematite.

\section{Behavior of manganese, magnesium and strontium}

The $\mathrm{Sr}^{2+}(1.13 \AA), \mathrm{Mn}^{2+}(0.80 \AA), \mathrm{Mn}^{3+}(0.64 \AA)$ and $\mathrm{Mg}^{2+}$ $(0.65 \AA)$ are cations that can readily substitute $\mathrm{Fe}^{2+}(0.76 \AA)$ and $\mathrm{Fe}^{3+}(0.64 \AA)$ in iron oxide minerals due to their charge density (Railsback 2003). The presence of these elements in martite granular hematite/martite (gHmA) (Figs. 9 and 10) was probably inherited from leached or oxidized carbonates from the sedimentary sequence that occupied the $\mathrm{Fe}^{2+}$ vacancies since the $\mathrm{Z} / \mathrm{r}$ ratio directly affects the strength of bonds in the mineral structures.

According to Yardley \& Bodnar (2014) and references therein, $\mathrm{Mn}$ and Fe have similar chemical behavior, being more soluble at analogous reducing conditions as $2^{+}$ions and becoming insoluble at oxidizing environments. The $\mathrm{Mn}^{2+}$ is present in larger concentrations in carbonates from DI and has been remobilized together with $\mathrm{Fe}^{2+}$ from oxides and

Table 4. Rare earth elements and yttrium data obtained by LA-ICP-MS for specularite crystals from the vein that cross-cut sample high-grade iron ore 2.

\begin{tabular}{|c|c|c|c|c|c|c|c|c|c|c|}
\hline \multirow{2}{*}{ Sample } & \multicolumn{10}{|c|}{ HIO2 (spH2B) } \\
\hline & 1 & 2 & 3 & 4 & 5 & 6 & 7 & 8 & 9 & 10 \\
\hline $\mathrm{La}$ & 0.279 & 0.015 & 0.163 & 0.473 & 0.117 & 0.011 & 0.850 & 0.100 & 0.209 & 0.119 \\
\hline $\mathrm{Ce}$ & 1.560 & 0.043 & 0.881 & 1.450 & 1.060 & 0.122 & 1.640 & 0.136 & 0.328 & 0.279 \\
\hline $\operatorname{Pr}$ & 0.030 & BDL & 0.019 & 0.138 & 0.011 & 0.005 & 0.075 & 0.008 & 0.015 & 0.018 \\
\hline Nd & 0.110 & BDL & 0.101 & 0.413 & 0.105 & 0.047 & 0.550 & 0.006 & 0.066 & 0.051 \\
\hline Sm & BDL & 0.020 & BDL & 0.155 & 0.018 & BDL & BDL & BDL & BDL & BDL \\
\hline $\mathrm{Eu}$ & 0.029 & 0.006 & $\mathrm{BDL}$ & 0.026 & 0.041 & 0.009 & $\mathrm{BDL}$ & BDL & 0.012 & 0.010 \\
\hline Gd & 0.061 & BDL & 0.085 & 0.252 & 0.102 & BDL & 0.059 & 0.010 & BDL & BDL \\
\hline $\mathrm{Tb}$ & 0.029 & BDL & BDL & 0.047 & 0.025 & BDL & BDL & 0.003 & BDL & 0.005 \\
\hline Dy & 0.145 & $\mathrm{BDL}$ & 0.151 & 0.273 & 0.189 & 0.006 & $\mathrm{BDL}$ & BDL & 0.033 & $\mathrm{BDL}$ \\
\hline Y & 0.430 & BDL & 0.549 & 1.190 & 0.510 & 0.028 & 0.080 & 0.035 & 0.060 & 0.060 \\
\hline Ho & 0.047 & 0.003 & BDL & 0.058 & 0.021 & BDL & BDL & BDL & 0.006 & BDL \\
\hline $\mathrm{Er}$ & 0.056 & BDL & 0.081 & 0.151 & 0.111 & BDL & 0.019 & BDL & 0.010 & BDL \\
\hline $\mathrm{Tm}$ & 0.012 & BDL & 0.014 & 0.024 & 0.021 & BDL & BDL & 0.002 & BDL & 0.003 \\
\hline $\mathrm{Yb}$ & BDL & BDL & 0.131 & 0.392 & 0.061 & 0.022 & 0.046 & BDL & BDL & BDL \\
\hline $\mathrm{Lu}$ & 0.024 & BDL & $\mathrm{BDL}$ & 0.024 & BDL & BDL & BDL & 0.002 & BDL & BDL \\
\hline$\Sigma \mathrm{REE}$ & 2.382 & 0.088 & 1.626 & 3.876 & 1.882 & 0.222 & 3.239 & 0.267 & 0.679 & 0.485 \\
\hline $\mathrm{La} / \mathrm{Yb}_{\mathrm{PAAS}}$ & & & 1.244 & 1.207 & 1.918 & 0.500 & 18.478 & & & \\
\hline $\mathrm{Sm} / \mathrm{Yb}_{\mathrm{PAAS}}$ & & & 0.000 & 0.395 & 0.295 & 0.000 & 0.000 & & & \\
\hline $\mathrm{Pr} / \mathrm{Pr}^{*}{ }_{\mathrm{PAAS}}$ & 0.297 & & 0.311 & 1.028 & 0.148 & 0.357 & 0.461 & 0.970 & 0.549 & 0.818 \\
\hline $\mathrm{Eu} / \mathrm{Eu}^{*}{ }_{\mathrm{PAAS}}$ & & & & 0.619 & 4.506 & & & & & \\
\hline $\mathrm{Y} / \mathrm{Y}^{*}{ }_{\mathrm{PAAS}}$ & 0.415 & & & 0.754 & 0.646 & & & & 0.329 & \\
\hline $\mathrm{Ce} / \mathrm{Ce}^{*}{ }_{\text {PAAS }}$ & 3.663 & 2.649 & 3.430 & 1.301 & 6.231 & 3.789 & 1.340 & 0.967 & 1.155 & 1.357 \\
\hline $\mathrm{Y} / \mathrm{Ho}$ & 9.149 & & & 20.517 & 24.286 & & & & 9.375 & \\
\hline
\end{tabular}

HIO2: high-grade iron ore 2; spH2B: elongated specularite from the quartz-specularite vein in high grade iron ore 2; BDL: below the detection limit; REE: rare earth elements; PAAS: Post Archean Average Shale. 
carbonates by reducing fluids. Under oxidizing conditions, it would have been precipitated as $\mathrm{Mn}^{3+}$ in trace amounts, occupying the $\mathrm{Fe}^{3+}$-octahedral sites of the specularite crystalline structure (sample HIO2).

The relatively low $\mathrm{Sr}$ content, compared to $\mathrm{Mn}$ and $\mathrm{Mg}$, could result from its larger ionic radius and difficulty in fitting in the crystalline structure of the iron oxides or simply reflect the lower concentration of this element in the carbonate protore. Alternatively, the values detected for these elements could represent the occurrence of submicroscopic particles of carbonates that remained as inclusions in the iron oxide grains.

\section{Behavior of chromium, titanium and vanadium}

The elements $\mathrm{Cr}, \mathrm{Ti}$, and $\mathrm{V}$ are lithophile and form cations with similar charge density $(\mathrm{Z} / \mathrm{r})$, as for example $\mathrm{Cr}^{3+}(\mathrm{r}=0.69 \AA), \mathrm{Cr}^{2+}(\mathrm{r}=0.90 \AA), \mathrm{V}^{4+}(\mathrm{r}=0.61 \AA), \mathrm{V}^{3+}$ $(\mathrm{r}=0.74 \AA), \mathrm{Ti}^{4+}(\mathrm{r}=0.68 \AA)$ and $\mathrm{Ti}^{3+}(\mathrm{r}=0.75 \AA)$, which would be capable of substituting $\mathrm{Fe}^{2+}$ and/or $\mathrm{Fe}^{3+}$ in the hematite and magnetite crystalline structure. The $\mathrm{Cr}$ and $\mathrm{V}$ contents obtained here show that these elements did not fractionate during the iron remobilization processes in the Esperança Deposit (Fig. 8). Nevertheless, the fractionation of $\mathrm{Ti}$, indicated in the variation of its contents in the different iron oxides, reveals a relative mobility of this element during mineralization.

\section{Rare earth elements and yttrium}

The REE-Y spidergram indicates that gHmA crystals in DI preserve the whole rock signature (Fig. 12).
Granular hematite from high-grade iron ore $(\mathrm{gHmB})$, however, exhibits a distinctive REE-Y pattern with a general depletion of HREE with respect to $\mathrm{gHmA}$ and a clear decrease in the Eu and $\mathrm{Y}$ anomalies. All generations of specular hematite crystals finally exhibit very low trace element concentrations compared to granular hematite. These changes suggest a progressive increase in the fluid/ rock ratio and probably inheritance of the signature of the mineralizing fluid.

A true negative Ce anomaly (sensu Bau \& Dulski 1996) is evident only in hematite crystals from DI and enclosed vein, similar to those values common in whole rock data from Paleoproterozoic BIFs, including the itabirites from the Quadrilátero Ferrífero (Spier et al. 2007). In hematite crystals from high-grade iron ore and also in the enclosed specularite in veins and vugs, a Ce anomaly is absent or positive (Fig. 13) indicating higher availability of this element in the fluid that would concentrate in the high-grade ore hematite and specularite plates under oxidative condition.

The variations of the element pair Y-Ho and of the Y/ Ho ratios indicate a $\mathrm{Y}$ mobilization during mineralization (Fig. 14). There is a progressive decrease in the Y/Ho values in the successive iron oxide generations from DI (near seawater field) to high-grade iron ore (CHARAC field) and then to specularite from fractures and veins (subchondritic ratios). This indicates that fluid composition and its chemical interactions with the country rocks played an important role in the geochemical signature of the iron oxides with progressive fractionation of $\mathrm{Y}$ and consequent decrease of

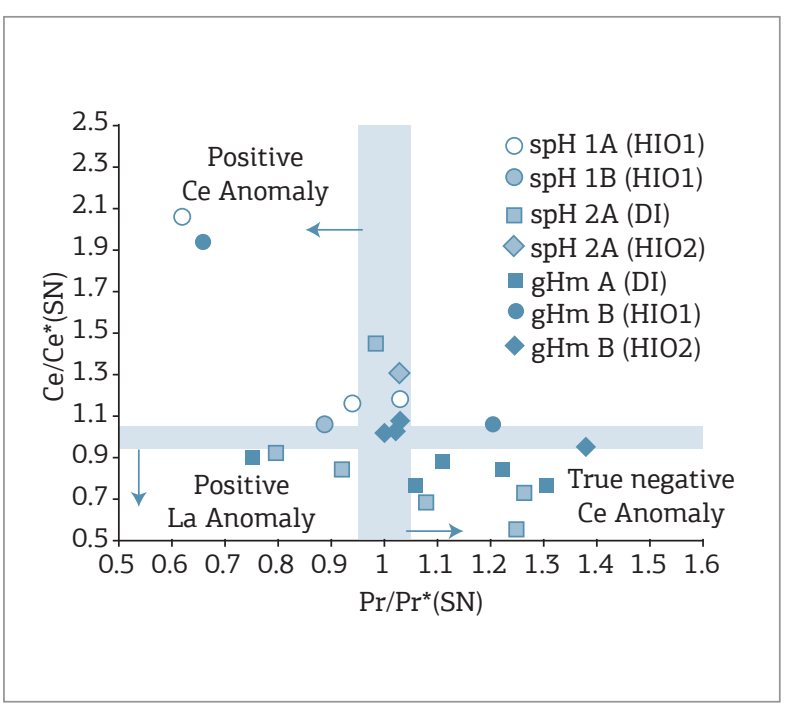

Figure 13. Discriminative plot of $\left(\mathrm{Ce} / \mathrm{Ce}^{*}\right)_{\mathrm{SN}}$ versus $\left(\mathrm{Pr} / \mathrm{Pr}^{*}\right)_{\mathrm{SN}}$. Negative Ce anomaly is defined by Bau \& Dulski 1996 as $\left(\mathrm{Ce} / \mathrm{Ce}^{*}\right)_{\mathrm{SN}}=\mathrm{Ce}_{\mathrm{SN}} /\left[0.5\left(\mathrm{Pr}_{\mathrm{SN}}+\mathrm{La}_{\mathrm{SN}}\right)\right]<1$ and $\left(\operatorname{Pr} / \mathrm{Pr}^{*}\right)_{\mathrm{SN}}=\mathrm{Pr}_{\mathrm{SN}} /\left[0.5\left(\mathrm{Ce}_{\mathrm{SN}}+0.5 \mathrm{Nd}_{\mathrm{SN}}\right)\right]>1$.

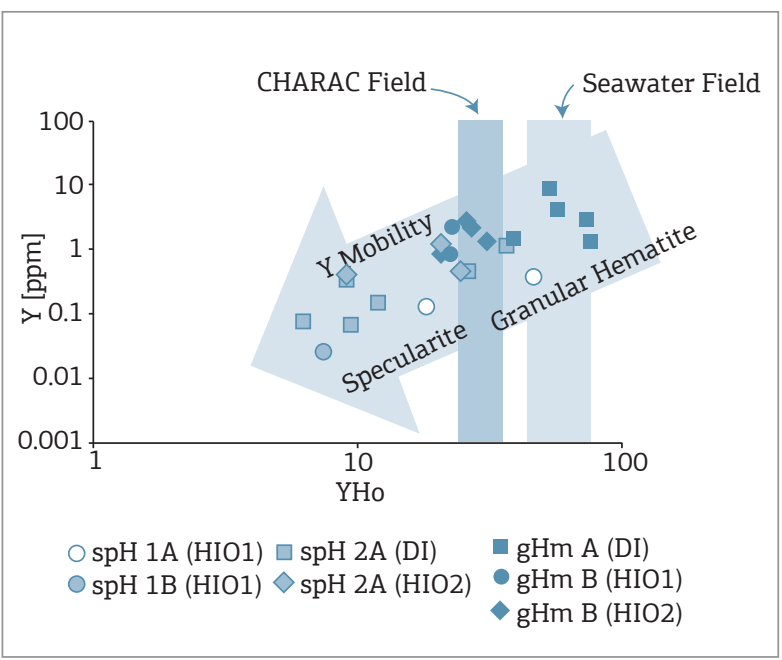

Figure 14. Yttrium versus Y/Ho diagram (Bau 1996) with data from all iron oxide generations from the three studied samples (DI, HIO1, and HIO2) from the Esperança Deposit. The results are compared with CHARAC and seawater field. 
the $\mathrm{Y} / \mathrm{Ho}$ ratio of the mineralizing fluid during its percolation and subsequent precipitation of the several specularite generations (Fig. 14).

\section{Chemical model}

The petrographic and geochemical analyses and interpretations of the data permitted a better understanding of the chemical changes which the ore components were subject to and allowed, therefore, the development of a conceptual model for iron enrichment processes in the Cauê BIF (Fig. 15).

\section{Characteristics of hematite from dolomitic itabirite}

Granular hematite/martite $(\mathrm{gHmA})$ is the main ore mineral both in DI and in the high-grade iron ore. This phase was formed during the early stages of mineralization (Rosière \& Rios 2004) and exhibits the highest contents in trace elements. The contents of $\mathrm{Mg}$, which is hosted by the kenomagnetite relics, were probably inherited from Mg-rich carbonate minerals from the DI protore. The REE-Y (PAAS-normalized) patterns and $\mathrm{Y} / \mathrm{Ho}$ ratios of the individual grains are very similar to the whole rock values found in unmineralized BIFs that also reflect the chemical affinity of the ore minerals with the host rock.

\section{Hydrothermal iron upgrade from dolomitic itabirite and formation of high-grade iron ore bodies}

The granular hematite/martite $(\mathrm{gHmB})$ grains from high-grade ore bodies are inherited from DI. The contents of relative immobile $\mathrm{V}, \mathrm{Cr}, \mathrm{Al}, \mathrm{Ga}, \mathrm{Si}, \mathrm{As}$, and $\mathrm{Sb}$ of $\mathrm{gHmB}$ are similar to gHmA but are depleted in $\mathrm{Sr}, \mathrm{Y}, \mathrm{Zr}, \mathrm{Ti}, \mathrm{Mg}$, and $\mathrm{Mn}$, suggesting that these elements were removed from the crystalline structure of the hematite during an iron mineralization stage dominated by leaching of gangue minerals and residual enrichment of $\mathrm{Fe}$.

\section{Iron remobilization and precipitation of hydrothermal specularite in syn kinematic vugs and veins}

Iron remobilization has also played an important role during mineralization. In this process, hypogene specularite crystals were precipitated in the available space created during deformation. Several generations of this mineral phase are highly depleted in all trace elements including REE with several values below the detection limit and highly variable $\mathrm{Y} / \mathrm{Ho}$ ratios ranging from chondritic to subchondritic. The positive Ce anomaly and the presence of $\mathrm{Mn}^{3+}$ in the structure of this mineral phase also indicate the highly oxidizing conditions.

Vein hosted plates of specularite precipitated with carbonates and quartz in the dolomitic rock $(\mathrm{spH} 2 \mathrm{~A})$ and with

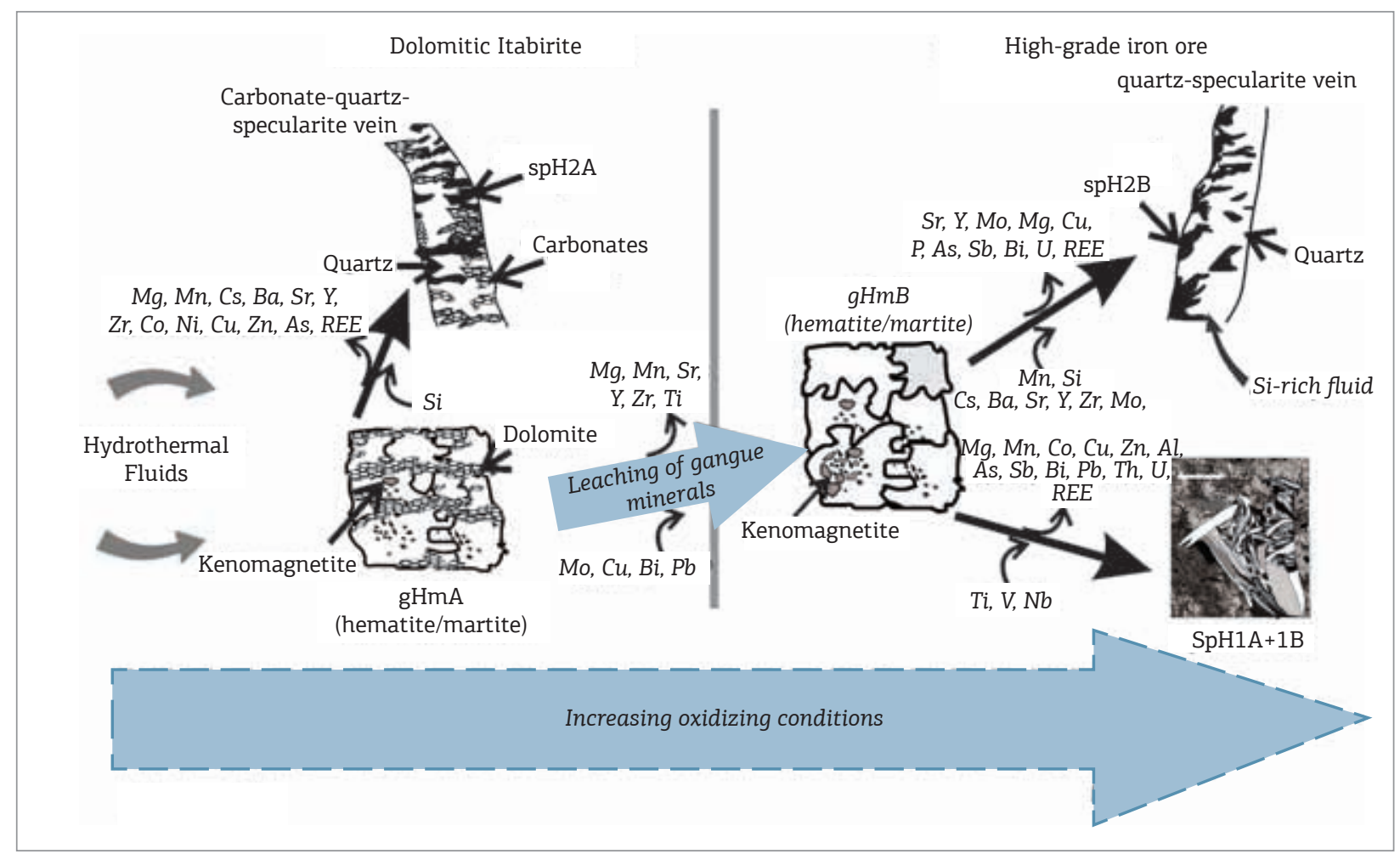

Figure 15. Schematic illustration of all iron oxide generations studied by LA-ICP-MS and its proposed sequence of formation. 
quartz $(\mathrm{spH} 2 \mathrm{~B})$ in the high-grade ore. In the central part of the veins, young specularite fibers have crystallized together with antitaxial, elongated quartz fibers, as well as with saccharoidal grains, indicating a late stage crack-seal mechanism with external input of $\mathrm{SiO}_{2}$-rich fluids. This mechanism was probably associated with the dissolution of quartz-rich country rocks at very high fluid-rock ratios, leading to the formation of dolomite-rich veins, which, in turn, possibly produced a large dilution thereby changing the Eh-pH conditions.

\section{CONCLUSIONS}

The LA-ICP-MS data presented in this paper allows the tracing of the signature of trace and REE elements in the different iron oxide mineral generations formed during the iron mineralization process in the Esperança Deposit, Quadrilátero Ferrífero.

The percolation of hydrothermal fluids through the host rocks has leached the gangue minerals, mainly carbonate and quartz, leaving a chemical signature of these minerals in the older granular hematite/martite from $\mathrm{DI}(\mathrm{gHmA})$ and highgrade iron ore $(\mathrm{gHmB})$. The specularite crystals from veins and vugs, which represent the youngest generation of iron oxides, present a chemical signature depleted in trace elements but with some important and distinctive chemical features such as $\mathrm{Mn}^{3+}$ contents, highly variable $\mathrm{Y} / \mathrm{Ho}$ ratios and positive $\mathrm{Ce}$ anomaly.

\section{ACKNOWLEDGEMENTS}

The financial support and infrastructure for this $\mathrm{PhD}$ study have been provided by Universidade Federal de Minas Gerais (UFMG), Comissão Nacional de Energia Nuclear/ Centro de Desenvolvimento da Tecnologia Nuclear (CNEN/ CDTN), Fundaçáo de Amparo à Pesquisa do Estado de Minas Gerais (FAPEMIG - CRA PPM 00179/13), Financiadora de Estudos e Projetos (FINEP - REDETEC 2715/09), Conselho Nacional de Desenvolvimento Científico e Tecnológico (CNPq -307546/2011-0) and the Laser Ablation ICPMS Analysis to NAP Geoanalítica - Universidade de São Paulo (USP) facilities. The authors thank H.P. Meireles and the Ferrous Resources for providing full access to geological information. We would like to thank S.P. Prates, T.A.F. Lima, L.E.D. Amorim, and the staff of Setor de Tecnologia Mineral (SETEM) from CNEN/CDTN, Brazil, for technical assistance and suggestions. A special thanks to the Section Editor, S. Hagemann, to both reviewers, and to the Chief Editor of the Brazilian Journal of Geology, U. Cordani, for the important collaboration with the improvement of this work.

\section{REFERENCES}

Alkmim F.F. \& Marshak S. 1998. Transamazonian orogeny in the Southern São Francisco Craton Region, Minas Gerais, Brazil: evidence for Paleoproterozoic collision and collapse in the Quadrilátero Ferrífero. Precambrian Research, 90:29-58.

Ávila C.A., Teixeira W., Cordani U.G., Moura C.A.V., Pereira R.M. 2010. Rhyacian $(2.23-2.20 \mathrm{Ga})$ juvenile accretion in the southern São Francisco Craton, Brazil: geochemical and isotopic evidence from the Serrinha magmatic suite, Mineiro belt. Journal of South American Earth Sciences, 29:464-482.

Bau M. 1996. Controls on the fractionation of isovalent trace elements in magmatic and aqueous systems: evidence from $\mathrm{Y} / \mathrm{Ho}$, $\mathrm{Zr} / \mathrm{Hf}$, and lanthanide tetrad effect. Contributions to Mineralogy and Petrology, 123(3):323-333.

Bau M. \& Dulski P. 1996. Distribution of yttrium and rare-earth elements in the Penge and Kuruman iron-formations, Transvaal Supergroup, South Africa. Precambrian Research, 79(1-2):37-55.

Beukes N.J., Gutzmer J., Mukhopadhyay J. 2003. The geology and genesis of high-grade hematite iron ore deposits. Applied Earth Science, 112:18-25.

Chemale Jr. F., Rosière C.A., Endo I. 1994. The tectonic evolution of the Quadrilátero Ferrífero, Minas Gerais, Brazil. Precambrian Research, 65:25-54.

Dorr J.V.N. 1964. Supergene iron ores of Minas Gerais, Brazil. Economic Geology, 59(7):1203-1239.
Dorr J.V.N. 1965. Nature and origin of the high-grade hematite ores of Minas Gerais, Brazil. Economic Geology, 60(1):1-46.

Dorr J.V.N. 1969. Physiographic, stratigraphic and structural development of the Quadrilátero Ferrifero, Minas Gerais. Washington, Geological Survey, Professional Paper 641-A, 110 p.

Dorr J.V.N. \& Barbosa A.L.M. 1963. Geology and ore deposits of the Itabira district, Minas Gerais, Brazil. Washington, Geological Survey, Professional Paper 341-C, $110 \mathrm{p}$

Eichler J.O. 1968. Enriquecimento residual e supergênico dos itabiritos através do intemperismo. Geology, I:29-40.

Gao S., Liu X., Yuan H., Hattendorf B., Gunther D., Hu S. 2002. Determination of forty two major and trace elements in SGS and NIST SRM glasses by laser ablation-inductively coupled plasmamass spectrometry. Geostandards Newsletter. The Journal of Geostandards and Geoanalysis, 26:181-196.

GEOREM. 2014. GeoReM: a new geochemical database for reference materials and isotopic standards. Disponível em: <http://georem. mpch-mainz.gwdg.de z. Acesso em: 20 out 2014.

Guild P.W. 1953. Iron deposits of the Congonhas District, Minas Gerais, Brazil. Economic Geology, 48(8):639-676.

Guild P.W. 1957. Geology and mineral resources of the Congonhas District, Minas Gerais, Brazil. Washington, Geological Survey, Professional Paper 290, 90 p. 
Hackspacher P.C. 1979. Strukturelle und texturelle Untersuchungen zur internen Deformation des Eisenreicherzkörpers der Grube "Aguas Claras" bei Belo Horizonte, Minas Gerais, Brasilien, v. 34. Clausthaler, Geologische Abhandlungen, $164 \mathrm{p}$.

Hagemann S.G., Barley M.E., Folkert S.L., Yardley B.W., Banks D.A. 1999. A hydrothermal origin for the Giant Tom Price Iron Ore Deposit. In: Stanley C.J. (ed.) Mineral deposits: process to processing. Rotterdam, Balkema, p. 41-44.

Hagemann S.G., Rosière C., Gutzmer J., Beukes N.J (eds). 2008. Banded iron formation-related high-grade iron ore. Reviews in Economic Geology, v. 15. Littleton, Society of Economic Geologists, Inc., 424 p.

Hagemann S.G., Rosière C.A., Lobato L.M., Baars F.J., Zucchetti M., Figueiredo e Silva R.C., Thorne W. 2005. Controversy in genetic models for high-grade BIF-related Fe deposits: unifying or discrete model(s)? In: Iron Ore 2005. Perth, Australasian Institute of Mining and Metallurgy, Publication Series n. 8/2005, p. 67-71.

Harmsworth R.A., Kneeshaw M., Morris R.C., Robinson C.J., Shrivastava P.K. 1990. BIF-derived iron-ores of the Hamersley Province. In: Hughes F.E. (ed.) Geology of the mineral deposits of Australia and Papua - New-Guinea. Melbourne, Australasian Institute of Mining and Metallurgy, $617 \mathrm{p}$.

Hartmann L.A., Endo I., Suita M.T.F., Santos J.O.S., Frantz J.C., Carneiro M.A., Mcnaughton N.J., Barley M.E. 2006. Provenance and age delimitation of Quadrilátero Ferrífero sandstones based on zircon U-Pb isotopes. Journal of South American Earth Sciences, 20:273-285

Horwitz W. 1982. Evaluation of analytical methods used for regulation of foods and drugs. Analytical Chemistry, 54(1):67-76A.

Kullerud G., Donnay G., Donnay J.D.H. 1969. Omission solid solution in magnetite: kenotetrahedral magnetite. Zeitschrifft der Kristallographie, 128:1-17.

Machado N. \& Carneiro M.A. 1992. U-Pb evidence of the late Archean tectono-thermal activity in the southern Sao Francisco shield, Brazil. Canadian Journal of Earth Sciences, 29:2341-2346.

Machado N., Noce C.M., Ladeira E.A., Belo de Oliveira O.A. 1992. $\mathrm{U}-\mathrm{Pb}$ geochronology of Archean magmatism and Proterozoic metamorphism in the Quadrilátero Ferrífero, southern São Francisco Craton, Brazil. Geological Society of America Bulletin, 104:1221-1227.

Machado N., Schrank A., Noce C.M., Gauthier G. 1996. Ages of detrital zircon from Archean-Paleoproterozoic sequences: implications for greenstone belt setting and evolution of a transamazonian foreland basin in Quadrilátero Ferrífero, southeast Brazil. Earth and Planetary Science Letters, 141:259-276.

McLennan S.B. 1989. Rare earth elements in sedimentary rocks. Influence of provenance and sedimentary processes. In: Lipin B.R. \& McKay G.A. (eds.) Geochemistry and mineralogy of the rare earth elements. Washington, Mineralogical Society of America, p. 169-200.

Melfi A.J., Pédro G., Nalovic L., Queiroz Neto J.P. 1976. Etude sur l'altération géochimique des itabirites du Brésil (dissolution du quartz et instabilité de l'hematite primaire en conditions tropicales hydrolysantes). Cahiers Orstom Série Pédologie, XIV(3):179-192.

Minami M., Masuda A., Takahashi K., Adachi M., Shimizu H. 1998. Y-Ho fractionation and lanthanide tetrad effect observed in cherts. Geochemical Journal, 32:405-419.

Morgan R., Orberger B., Rosière C.A., Wirth R., Mota Carvalho C.D., Bellver-Baca M.T. 2013. The origin of coexisting carbonates in banded iron formations: a micro-mineralogical study of the $2.4 \mathrm{Ga}$ Itabira Group, Brazil. Precambrian Research, 224:491-511.
Morris R.C. 1980. Textural and mineralogical study of the relationship of iron ore to banded iron formation in the Hamersley Iron Province of Western Australia. Economic Geology, 75(2):184-209.

Morris R.C.A. 1987. Iron ores derived by enrichment of banded iron formation. In: Hein J.R (ed.) The genesis of ores and petroleum associated with sedimentary siliceous deposits. New York, Van Nostrand Reinhold Company, p. 231-267.

Nadoll P., Angerer T., Mauk J.L., French D., Walshe J. 2014. The chemistry of hydrothermal magnetite: a review. Ore Geology Reviews, 61:1-32.

Noce C.M., Machado N., Teixeira W. 1998. U-Pb geochronology of gneisses and granitoids in the Quadrilátero Ferrífero (Southern São Francisco craton): age constraints for Archean and Paleoproterozoic magmatism and metamorphism. Revista Brasileira de Geociências, 28:95-102.

Nozaki Y., Zhang J., Amakawa H. 1997. The fractionation between $\mathrm{Y}$ and Ho in the marine environment. Earth and Planetary Science Letters, 148:329-340.

Planavsky N., Bekker A., Rouxel O.J., Kamber B., Hofmann A., Knudsen A., Lyons T.W. 2010. Rare earth element and yttrium compositions of Archean and Paleoproterozoic Fe formations revisited: new perspectives on the significance and mechanisms of deposition. Geochimica et Coscochimica Acta, 74:6387-6405.

Powell A.C., Oliver N., Li Z.X., Martin B.D., Ronaszeki J. 1999. Synorogenic hydrothermal origin for giant Hamersley iron oxide ore bodies. Geology, 27(2):175-178.

Railsback L.B. 2003. An earth scientist's periodic table of the elements and their ions. Geology, 31(9):737-740.

Renger F.E., Noce C.M., Romano A.W., Machado N. 1994. Evolução sedimentar do Supergrupo Minas: 500 Ma. de registro geológico no Quadrilátero Ferrífero, Minas Gerais, Brasil. Geonomos, 2(1):1-11.

Rosière C.A. 1981. Strukturelle und Texturelle Untersuchungen in der Eisenerzlagerstaette "Pico de Itabira" bei Itabirito, Minas Gerais, Brasilien. Geowissenschaftliche Dissertationen, v. 9. Clausthal, Technische Universität Clausthal, 302 p.

Rosière C.A. \& Chemale Jr. F. 1991. Textural and structural aspects of iron ores from Iron Quadrangle, Brazil. In: Pagel M. \& Leroy J.L. (eds.) Source, transport and deposition of metals: proceedings of the 25 years. Nancy, Balkema, Society for Geology Applied to Mineral Deposits Anniversary Meeting, p. 485-489.

Rosière C.A., Garcia O.L., Siemens H., Schaeben H. 2013a. Domainal fabrics of hematite in schistose, shear zone-hosted high-grade Fe ores: the product of the interplay between deformation and mineralization. Journal of Structural Geology, 55:150-166.

Rosière C.A. \& Rios F.J. 2004. The origin of hematite in high-grade iron ores based on infrared microscopy and fluid inclusion studies: the example of the Conceição Mine, Quadrilátero Ferrífero, Brazil. Economic Geology, 99:611-624.

Rosière C.A., Sanglard J., Sabadini Jr. R., Hensler A.-S., Hagemann S., Santos J.O.S., McNaughton N., Fletcher I. 2013b. Iron mineralization in the Quadrilátero Ferrífero: structural control, age and mineralchemical changes. In: $12^{\text {th }}$ SGA Biennial Meeting, Mineral Deposit Research for a High-Tech World, Uppsala, Annais.

Rosière C.A., Siemes H., Quade H., Brokmeier H.G., Jansen E. 2001. Microstructures, textures and deformation mechanisms in hematite. Journal of Structural Geology, 23(8):1429-1440.

Rosière C.A., Spier C.A., Rios F.J., Suckau V.E. 2008. The itabirite from the Quadrilátero Ferrífero and related high-grade ores: an overview. Reviews in Economic Geology, 15:223-254. 
Sanglard J.C.D. 2013. Geologia estrutural do segmento oeste da Serra do Curral, Quadrilátero Ferrífero, e o controle tectônico das acumulações de alto teor em Fe. MS Dissertation, Instituto de Geociências, Universidade Federal de Minas Gerais, Belo Horizonte, $79 \mathrm{p}$.

Sanglard J.C.D., Rosière C.A., Suckau V.E., Amaral U., Meireles H. 2011. The structure of the western Serra do Curral Range, Quadrilátero Ferriffero and the tectonic control of the high-grade Fe-orebodies. In: $11^{\text {th }}$ SGA Biennial Meeting, Antofagasta, p. 879-881.

Spier C.A., Oliveira S.M.B., Rosière C.A. 2003. Geology and geochemistry of the Águas Claras and Pico iron mines, Quadrilátero Ferrífero, Minas Gerais, Brazil. Mineralium Deposita, 38:751-774
Spier C.A., Oliveira S.M.B., Sial A.N., Rios F.J. 2007. Geochemistry and genesis of the banded iron formations of the Cauê Formation, Quadrilátero Ferrífero, Minas Gerais, Brazil. Precambrian Research, 152(3-4):170-206

Taylor D., Dalstra H.J., Harding A.E., Broadbent G.C., Barley M.E. 2001. Genesis of high-grade hematite orebodies of the Hamersley Province, Western Australia. Economic Geology, 96(4):837-873.

Yardley B.W.D. \& Bodnar R.J. 2014. Fluids in the continental crust. Geochemical Perspectives, v. 3, n. 1. The Netherlands, European Association of Geochemistry, 127 p.

Arquivo digital disponível on-line no site www.sbgeo.org.br 
Appendix 1. Quantitative data obtained for BHVO-2G reference material for quality control during the LA-ICP-MS analyses of iron oxides from Esperança Deposit, Quadrilátero Ferrífero, Brazil.

\begin{tabular}{|c|c|c|c|c|c|c|c|c|c|c|}
\hline \multirow{3}{*}{$\begin{array}{l}\text { Element } \\
\mathrm{Li}^{7}\end{array}$} & \multicolumn{4}{|c|}{ BHVO-2 (obtained) } & \multicolumn{3}{|c|}{ Gao et al. (2002) } & \multirow{3}{*}{$\begin{array}{c}\text { CV (\%) } \\
93\end{array}$} & \multirow{2}{*}{\multicolumn{2}{|c|}{$\begin{array}{l}\text { Tolerance } \\
\text { of CV (\%) }\end{array}$}} \\
\hline & \multirow{2}{*}{$\begin{array}{c}\text { Median } \\
4.62\end{array}$} & \multirow{2}{*}{$\begin{array}{c}\text { Mean } \\
4.64\end{array}$} & \multirow{2}{*}{$\begin{array}{c}\mathbf{s} \\
0.40\end{array}$} & \multirow{2}{*}{$\begin{array}{l}n \\
9\end{array}$} & \multirow{2}{*}{$\begin{array}{c}\text { Value } \\
5.00\end{array}$} & \multirow{2}{*}{$\begin{array}{c}\mathbf{s} \\
0.40\end{array}$} & \multirow{2}{*}{$\frac{n}{26}$} & & & \\
\hline & & & & & & & & & 80 & 120 \\
\hline $\mathrm{Na}^{23}$ & 16,211 & 15,680 & 1,456 & 9 & 17,672 & 443 & 29 & 89 & 80 & 120 \\
\hline $\mathrm{Mg}^{26}$ & 45,094 & 45,037 & 2,161 & 9 & 42,682 & 1071 & 25 & 106 & 80 & 120 \\
\hline $\mathrm{Al}^{27}$ & 84,134 & 82,183 & 8,367 & 9 & 71,974 & 529 & 25 & 114 & 80 & 120 \\
\hline $\mathrm{Si}^{29}$ & 278,845 & 283,269 & 24,434 & 9 & 230,460 & 467 & $\mathrm{EPMA}^{(1)}$ & $123^{*}$ & 80 & 120 \\
\hline $\mathrm{P}^{31}$ & 1,157 & 1,225 & 142 & 9 & 1,266 & 87 & $\mathrm{EPMA}^{(1)}$ & 97 & 80 & 120 \\
\hline $\mathrm{Ti}^{49}$ & 17,573 & 17,555 & 1,152 & 9 & 15,621 & 453 & 53 & 112 & 80 & 120 \\
\hline $\mathrm{V}^{51}$ & 353 & 354 & 14 & 9 & 329 & 9 & 42 & 108 & 80 & 120 \\
\hline $\mathrm{Cr}^{53}$ & 310 & 308 & 13 & 9 & 285 & 14 & 51 & 108 & 80 & 120 \\
\hline $\mathrm{Mn}^{55}$ & 1,355 & 1,394 & 105 & 9 & 1,345 & 25 & 22 & 104 & 80 & 120 \\
\hline $\mathrm{Fe}^{57}$ & 87,836 & 87,836 & 0 & 9 & 87,836 & 777 & $\mathrm{EPMA}^{(1)}$ & 100 & 80 & 120 \\
\hline $\mathrm{Co}^{59}$ & 47.1 & 47.2 & 3.0 & 9 & 47.0 & 2.0 & 53 & 100 & 80 & 120 \\
\hline $\mathrm{Ni}^{60}$ & 123 & 121 & 13 & 9 & 112 & 9 & 48 & 108 & 80 & 120 \\
\hline $\mathrm{Cu}^{63}$ & 125 & 123 & 11 & 9 & 142 & 10 & 52 & 87 & 80 & 120 \\
\hline $\mathrm{Zn}^{66}$ & 113 & 114 & 7 & 9 & 107 & 26 & 36 & 106 & 80 & 120 \\
\hline $\mathrm{Ga}^{71}$ & 22.0 & 21.9 & 1.6 & 9 & 21.0 & 1.0 & 44 & 104 & 80 & 120 \\
\hline $\mathrm{As}^{75}$ & 0.84 & 0.87 & 0.18 & 7 & n.d & & & & 80 & 120 \\
\hline $\mathrm{Sr}^{88}$ & 411 & 429 & 46 & 9 & 382 & 10 & 53 & 112 & 80 & 120 \\
\hline $\mathrm{Y}^{89}$ & 23.9 & 23.9 & 2.6 & 9 & 23.0 & 1.0 & 57 & 104 & 80 & 120 \\
\hline $\mathrm{Zr}^{90}$ & 173 & 167 & 24 & 9 & 160 & 8.0 & 56 & 104 & 80 & 120 \\
\hline $\mathrm{Nb}^{93}$ & 17.8 & 19.3 & 2.4 & 9 & 16.4 & 0.7 & 56 & 118 & 80 & 120 \\
\hline $\mathrm{Mo}^{95}$ & 4.43 & 4.22 & 0.50 & 9 & n.d. & & & & 80 & 120 \\
\hline $\mathrm{Sb}^{121}$ & 0.12 & 0.12 & 0.06 & 6 & 0.21 & 0.04 & 10 & $56^{* *}$ & 80 & 120 \\
\hline $\mathrm{Cs}^{133}$ & 0.09 & 0.09 & 0.01 & 9 & 0.11 & 0.02 & 29 & 86 & 80 & 120 \\
\hline $\mathrm{Ba}^{137}$ & 132 & 133 & 9 & 9 & 128 & 4 & 56 & 104 & 80 & 120 \\
\hline $\mathrm{La}^{139}$ & 17.0 & 17.1 & 2.1 & 9 & 15.6 & 0.6 & 38 & 109 & 80 & 120 \\
\hline $\mathrm{Ce}^{140}$ & 40.8 & 41.4 & 3.2 & 9 & 37.0 & 1.0 & 32 & 112 & 80 & 120 \\
\hline $\operatorname{Pr}^{141}$ & 5.47 & 5.63 & 0.49 & 9 & 5.00 & 0.30 & 33 & 113 & 80 & 120 \\
\hline $\mathrm{Nd}^{144}$ & 23.4 & 23.3 & 2.3 & 9 & 24.0 & 1.0 & 32 & 97 & 80 & 120 \\
\hline $\mathrm{Sm}^{147}$ & 6.57 & 6.44 & 0.79 & 9 & 5.80 & 0.50 & 32 & 111 & 80 & 120 \\
\hline $\mathrm{Eu}^{153}$ & 2.29 & 2.30 & 0.14 & 9 & 2.00 & 0.10 & 28 & 115 & 80 & 120 \\
\hline $\mathrm{Gd}^{156}$ & 6.17 & 6.16 & 0.84 & 9 & 5.90 & 0.40 & 30 & 104 & 80 & 120 \\
\hline $\mathrm{Tb}^{159}$ & 0.91 & 0.91 & 0.08 & 9 & 0.86 & 0.06 & 31 & 105 & 80 & 120 \\
\hline $\mathrm{Dy}^{161}$ & 5.28 & 5.10 & 0.54 & 9 & 4.90 & 0.40 & 33 & 104 & 80 & 120 \\
\hline $\mathrm{Ho}^{165}$ & 1.00 & 0.99 & 0.12 & 9 & 0.91 & 0.06 & 32 & 108 & 80 & 120 \\
\hline $\mathrm{Er}^{166}$ & 2.38 & 2.31 & 0.30 & 9 & 2.30 & 0.20 & 28 & 101 & 80 & 120 \\
\hline $\mathrm{Tm}^{169}$ & 0.31 & 0.30 & 0.02 & 9 & 0.30 & 0.05 & 32 & 101 & 80 & 120 \\
\hline $\mathrm{Yb}^{173}$ & 2.11 & 2.01 & 0.29 & 9 & 2.00 & 0.20 & 30 & 101 & 80 & 120 \\
\hline $\mathrm{Lu}^{175}$ & 0.28 & 0.27 & 0.03 & 9 & 0.26 & 0.04 & 29 & 103 & 80 & 120 \\
\hline $\mathrm{Pb}^{208}$ & 1.89 & 1.92 & 0.26 & 9 & 1.40 & 0.20 & 43 & $137^{*}$ & 80 & 120 \\
\hline $\mathrm{Bi}^{209}$ & 0.02 & 0.02 & 0.01 & 6 & n.d. & & & & 80 & 120 \\
\hline $\mathrm{Th}^{232}$ & 1.27 & 1.27 & 0.15 & 9 & 1.18 & 0.09 & 48 & 107 & 80 & 120 \\
\hline $\mathrm{U}^{238}$ & 0.45 & 0.47 & 0.06 & 9 & 0.44 & 0.03 & 42 & 107 & 80 & 120 \\
\hline
\end{tabular}

EPMA $^{(1)}$ : Electron Probe Micro-Analyser - GEOREM (2014); *probably this isotope needs more data to improve the results; ${ }^{* *}<$ QL (quantitation limit). $\mathrm{CV}(\%)=($ obtained value / Gao et al. $(2002)$ value $) * 100$.

CV: coefficients of variation; n: number of analysis; s: standard deviation; n.d.: not detected. 
Lucilia Aparecida Ramos de Oliveira et al.

Appendix 2. Results obtained for BHVO-2G reference material for quality control during the LA-ICP-MS analyses of iron oxides from Esperança Deposit, Quadrilátero Ferrífero, Brazil.

\begin{tabular}{|c|c|c|c|c|c|c|c|c|c|}
\hline \multirow{2}{*}{ Element } & \multicolumn{2}{|c|}{ HIO1 } & \multicolumn{3}{|c|}{ HIO2 } & \multicolumn{4}{|c|}{ DI } \\
\hline & 1 & 2 & 3 & 4 & 5 & 6 & 7 & 8 & 9 \\
\hline $\mathrm{Li}^{7}$ & 4.32 & 4.98 & 4.62 & 4.15 & 5.10 & 4.51 & 5.08 & 4.07 & 4.89 \\
\hline $\mathrm{Na}^{23}$ & 12,711 & 15,030 & 16,920 & 16,210 & 16,251 & 16,491 & 17,554 & 15,425 & 14,521 \\
\hline $\mathrm{Mg}^{26}$ & 42,799 & 48,433 & 45,094 & 43,572 & 42,728 & 45,286 & 47,115 & 47,264 & 43,038 \\
\hline $\mathrm{Al}^{27}$ & 71,646 & 87,946 & 85,042 & 84,133 & 83,598 & 90,131 & 93,355 & 70,833 & 72,957 \\
\hline $\mathrm{Si}^{29}$ & 284,253 & 313,726 & 262,238 & 258,036 & 265,656 & 297,545 & 278,845 & 263,095 & 326,014 \\
\hline $\mathrm{P}^{31}$ & 1,349 & 1,469 & 1,094 & 1,082 & 1,116 & 1,119 & 1,157 & 1,278 & 1,360 \\
\hline $\mathrm{Ti}^{49}$ & 16,011 & 18,881 & 17,134 & 17,572 & 16,862 & 18,660 & 18,345 & 15,885 & 18,645 \\
\hline $\mathrm{V}^{51}$ & 330 & 362 & 357 & 361 & 353 & 344 & 346 & 348 & 381 \\
\hline $\mathrm{Cr}^{53}$ & 290 & 333 & 315 & 311 & 316 & 300 & 295 & 310 & 299 \\
\hline $\mathrm{Mn}^{55}$ & 1,538 & 1,595 & 1,386 & 1355 & 1325 & 1297 & 1,408 & 1,327 & 1,308 \\
\hline $\mathrm{Fe}^{57}$ & 87,836 & 87,836 & 87,836 & 87,836 & 87,836 & 87,836 & 87,836 & 87,836 & 87,836 \\
\hline $\mathrm{Co}^{59}$ & 47.1 & 52.9 & 49.2 & 48.7 & 46.8 & 45.6 & 47.9 & 42.2 & 44.5 \\
\hline $\mathrm{Ni}^{60}$ & 103 & 132 & 132 & 134 & 126 & 122 & 118 & 115 & 100 \\
\hline $\mathrm{Cu}^{63}$ & 104 & 115 & 127 & 125 & 122 & 140 & 130 & 129 & 110 \\
\hline $\mathrm{Zn}^{66}$ & 115 & 112 & 121 & 110 & 114 & 113 & 100 & 127 & 108 \\
\hline $\mathrm{Ga}^{71}$ & 19.6 & 22.0 & 24.6 & 22.7 & 22.6 & 22.8 & 21.6 & 21.8 & 19.6 \\
\hline $\mathrm{As}^{75}$ & 1.06 & $<0.64$ & 0.84 & 0.59 & 1.13 & 0.78 & 0.91 & $<0.77$ & 0.76 \\
\hline $\mathrm{Sr}^{88}$ & 408 & 528 & 410 & 406 & 400 & 385 & 412 & 424 & 480 \\
\hline $\mathrm{Y}^{89}$ & 21.2 & 24.6 & 23.8 & 25.0 & 23.8 & 25.7 & 27.7 & 18.8 & 23.8 \\
\hline $\mathrm{Zr}^{90}$ & 135 & 154 & 172 & 179 & 174 & 190 & 201 & 131 & 159 \\
\hline $\mathrm{Nb}^{93}$ & 17.3 & 22.8 & 17.8 & 17.6 & 17.0 & 22.0 & 22.1 & 17.3 & 19.6 \\
\hline $\mathrm{Mo}^{95}$ & 3.10 & 4.55 & 4.43 & 4.51 & 3.76 & 4.35 & 4.61 & 4.12 & 4.58 \\
\hline $\mathrm{Sb}^{121}$ & $<0.119$ & $<0.129$ & 0.06 & 0.14 & 0.06 & 0.10 & 0.14 & $<0.119$ & 0.21 \\
\hline $\mathrm{Cs}^{133}$ & 0.09 & 0.12 & 0.09 & 0.09 & 0.09 & 0.11 & 0.09 & 0.08 & 0.09 \\
\hline $\mathrm{Ba}^{137}$ & 126 & 153 & 134 & 128 & 133 & 136 & 131 & 122 & 131 \\
\hline $\mathrm{La}^{139}$ & 17.0 & 21.5 & 17.4 & 17.6 & 17.3 & 16.1 & 16.5 & 13.6 & 16.3 \\
\hline $\mathrm{Ce}^{140}$ & 41.0 & 49.3 & 39.6 & 39.6 & 40.7 & 38.6 & 39.2 & 42.1 & 41.9 \\
\hline $\mathrm{Pr}^{141}$ & 5.47 & 6.82 & 5.38 & 5.28 & 5.36 & 5.52 & 5.89 & 5.28 & 5.64 \\
\hline $\mathrm{Nd}^{144}$ & 20.7 & 26.3 & 25.0 & 23.3 & 22.8 & 24.3 & 24.8 & 18.9 & 23.3 \\
\hline $\mathrm{Sm}^{147}$ & 5.81 & 7.76 & 6.60 & 6.57 & 6.40 & 6.88 & 6.51 & 4.85 & 6.60 \\
\hline $\mathrm{Eu}^{153}$ & 2.43 & 2.54 & 2.29 & 2.31 & 2.42 & 2.12 & 2.27 & 2.10 & 2.26 \\
\hline $\mathrm{Gd}^{156}$ & 5.02 & 7.46 & 6.21 & 6.17 & 6.09 & 7.10 & 6.63 & 5.01 & 5.74 \\
\hline $\mathrm{Tb}^{159}$ & 0.87 & 0.77 & 0.99 & 0.96 & 0.91 & 0.97 & 0.97 & 0.79 & 0.91 \\
\hline $\mathrm{Dy}^{161}$ & 4.09 & 5.48 & 5.14 & 5.29 & 5.67 & 5.28 & 5.65 & 4.58 & 4.69 \\
\hline $\mathrm{Ho}^{165}$ & 0.84 & 1.21 & 0.97 & 1.00 & 1.03 & 1.02 & 1.06 & 0.81 & 0.93 \\
\hline $\mathrm{Er}^{166}$ & 2.14 & 2.27 & 2.46 & 2.38 & 2.42 & 2.58 & 2.76 & 1.72 & 2.09 \\
\hline $\mathrm{Tm}^{169}$ & 0.26 & 0.28 & 0.32 & 0.31 & 0.31 & 0.33 & 0.33 & 0.29 & 0.29 \\
\hline $\mathrm{Yb}^{173}$ & 2.11 & 2.20 & 2.04 & 2.17 & 1.95 & 2.34 & 2.20 & 1.58 & 1.51 \\
\hline $\mathrm{Lu}^{175}$ & 0.23 & 0.26 & 0.29 & 0.29 & 0.30 & 0.30 & 0.28 & 0.23 & 0.24 \\
\hline $\mathrm{Pb}^{208}$ & 1.89 & 1.82 & 1.89 & 1.68 & 1.73 & 1.89 & 1.69 & 2.41 & 2.32 \\
\hline $\mathrm{Bi}^{209}$ & 0.05 & $<0.024$ & 0.02 & 0.01 & $<0.0096$ & 0.02 & 0.03 & $<0.033$ & 0.03 \\
\hline $\mathrm{Th}^{232}$ & 1.06 & 1.42 & 1.27 & 1.33 & 1.27 & 1.51 & 1.25 & 1.06 & 1.22 \\
\hline $\mathrm{U}^{238}$ & 0.45 & 0.61 & 0.47 & 0.45 & 0.44 & 0.50 & 0.51 & 0.42 & 0.41 \\
\hline
\end{tabular}

${ }^{*}$ All values in ppm.

HIO1: high-grade iron ore 1; HIO2: high-grade iron ore 2; DI: dolomitic itabirite. 
Appendix 3. Results of statistics calculations for the detection limit of the trace elements obtained by LA-ICPMS during analyzes of iron oxides from dolomitic itabirite and high-grade iron ore from Esperança Deposit, Quadrilátero Ferrífero, Brazil.

\begin{tabular}{|c|c|c|c|c|c|c|}
\hline \multirow{2}{*}{ Element } & \multicolumn{4}{|c|}{ Detection limit obtained } & \multirow{2}{*}{ DL } & \multirow{2}{*}{ QL } \\
\hline & Median & Mean & $\mathbf{s}$ & 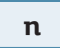 & & \\
\hline $\mathrm{Li}^{7}$ & 0.36 & 0.41 & 0.22 & 33 & 0.41 & 1.35 \\
\hline $\mathrm{Na}^{23}$ & 0.43 & 0.44 & 0.22 & 38 & 0.44 & 1.47 \\
\hline $\mathrm{Mg}^{26}$ & 3.18 & 3.39 & 1.67 & 38 & 3.39 & 11.3 \\
\hline $\mathrm{Al}^{27}$ & 0.67 & 0.70 & 0.33 & 38 & 0.70 & 2.33 \\
\hline $\mathrm{Si}^{29}$ & 179 & 187 & 88 & 38 & 187 & 623 \\
\hline $\mathrm{P}^{31}$ & 11.3 & 12.0 & 5.68 & 38 & 12.0 & 39.9 \\
\hline $\mathrm{Ti}^{49}$ & 0.70 & 0.79 & 0.39 & 29 & 0.79 & 2.62 \\
\hline $\mathrm{V}^{51}$ & 0.10 & 0.11 & 0.05 & 38 & 0.11 & 0.35 \\
\hline $\mathrm{Cr}^{53}$ & 1.43 & 1.45 & 0.67 & 38 & 1.45 & 4.82 \\
\hline $\mathrm{Mn}^{55}$ & 0.30 & 0.30 & 0.14 & 38 & 0.30 & 1.00 \\
\hline $\mathrm{Fe}^{57}$ & 8.21 & 8.73 & 4.31 & 38 & 8.73 & 29.07 \\
\hline $\mathrm{Co}^{59}$ & 0.06 & 0.06 & 0.03 & 22 & 0.06 & 0.20 \\
\hline $\mathrm{Ni}^{60}$ & 0.24 & 0.25 & 0.12 & 23 & 0.25 & 0.82 \\
\hline $\mathrm{Cu}^{63}$ & 0.10 & 0.11 & 0.06 & 31 & 0.11 & 0.37 \\
\hline $\mathrm{Zn}^{66}$ & 0.50 & 0.50 & 0.20 & 38 & 0.50 & 1.66 \\
\hline $\mathrm{Ga}^{71}$ & 0.07 & 0.07 & 0.03 & 28 & 0.07 & 0.25 \\
\hline $\mathrm{As}^{75}$ & 0.39 & 0.42 & 0.19 & 38 & 0.42 & 1.39 \\
\hline $\mathrm{Sr}^{88}$ & 0.01 & 0.01 & 0.01 & 23 & 0.01 & 0.05 \\
\hline $\mathrm{Y}^{89}$ & 0.01 & 0.02 & 0.01 & 16 & 0.02 & 0.05 \\
\hline $\mathrm{Zr}^{90}$ & 0.03 & 0.03 & 0.02 & 18 & 0.03 & 0.11 \\
\hline $\mathrm{Nb}^{93}$ & 0.02 & 0.02 & 0.02 & 25 & 0.02 & 0.08 \\
\hline $\mathrm{Mo}^{95}$ & 0.10 & 0.10 & 0.04 & 19 & 0.10 & 0.32 \\
\hline $\mathrm{Sb}^{121}$ & 0.05 & 0.05 & 0.03 & 27 & 0.05 & 0.18 \\
\hline $\mathrm{Cs}^{133}$ & 0.02 & 0.02 & 0.01 & 37 & 0.02 & 0.08 \\
\hline $\mathrm{Ba}^{137}$ & 0.09 & 0.10 & 0.06 & 15 & 0.10 & 0.33 \\
\hline $\mathrm{La}^{139}$ & 0.01 & 0.01 & 0.00 & 33 & 0.01 & 0.02 \\
\hline $\mathrm{Ce}^{140}$ & 0.01 & 0.01 & 0.00 & 31 & 0.01 & 0.02 \\
\hline $\operatorname{Pr}^{141}$ & 0.01 & 0.01 & 0.00 & 27 & 0.01 & 0.02 \\
\hline $\mathrm{Nd}^{144}$ & 0.03 & 0.03 & 0.02 & 25 & 0.03 & 0.10 \\
\hline $\mathrm{Sm}^{147}$ & 0.05 & 0.05 & 0.03 & 28 & 0.05 & 0.17 \\
\hline $\mathrm{Eu}^{153}$ & 0.01 & 0.01 & 0.01 & 26 & 0.01 & 0.05 \\
\hline $\mathrm{Gd}^{156}$ & 0.04 & 0.05 & 0.03 & 26 & 0.05 & 0.18 \\
\hline $\mathrm{Tb}^{159}$ & 0.01 & 0.01 & 0.00 & 32 & 0.01 & 0.03 \\
\hline $\mathrm{Dy}^{161}$ & 0.04 & 0.04 & 0.02 & 29 & 0.04 & 0.14 \\
\hline $\mathrm{Ho}^{165}$ & 0.01 & 0.01 & 0.00 & 22 & 0.01 & 0.03 \\
\hline $\mathrm{Er}^{166}$ & 0.02 & 0.02 & 0.01 & 29 & 0.02 & 0.07 \\
\hline $\mathrm{Tm}^{169}$ & 0.01 & 0.01 & 0.00 & 26 & 0.01 & 0.03 \\
\hline $\mathrm{Yb}^{173}$ & 0.05 & 0.05 & 0.03 & 23 & 0.05 & 0.17 \\
\hline $\mathrm{Lu}^{175}$ & 0.01 & 0.01 & 0.01 & 24 & 0.01 & 0.03 \\
\hline $\mathrm{Pb}^{208}$ & 0.03 & 0.03 & 0.02 & 30 & 0.03 & 0.11 \\
\hline $\mathrm{Bi}^{209}$ & 0.02 & 0.02 & 0.01 & 19 & 0.02 & 0.07 \\
\hline $\mathrm{Th}^{232}$ & 0.02 & 0.02 & 0.01 & 18 & 0.02 & 0.08 \\
\hline $\mathrm{U}^{238}$ & 0.02 & 0.02 & 0.01 & 15 & 0.02 & 0.07 \\
\hline
\end{tabular}

Median: central number of a set (ppm); Mean: average (ppm); s: standard deviation; n: number of analysis; DL: detection limit of $99 \%$ of CL ( 3 s); QL: quantitation limit of $99 \%$ CL ( 10 s or 3.33 DL); CL: confidence limit. 